\title{
'Overthickening' of Sedimentary Sequences by Igneous Intrusions
}

INIALL MARK*, 'NICK SCHOFIELD, '2DAVID GARDINER, ' ${ }^{3} I A M$ HOLT, ${ }^{3}$ CLAYTON GROVE, IDOUGLAS WATSON, ${ }^{3}$ ANDY ALEXANDER, ${ }^{3}$ HEATHER POORE

'Department of Geology and Petroleum Geology, University of Aberdeen, Aberdeen AB24 3UE, UK

2Integrated Geochemical Interpretation Ltd, The Granary, Hallsannery, Bideford, Devon, EX39 5HE, UK

${ }^{3}$ Siccar Point Energy Limited, Hill of Rubislaw, Anderson Drive, Aberdeen, ABI5 6BY, UK

*Corresponding author (e-mail: niall.mark@abdn.ac.uk)

\section{ABSTRACT}

The identification of extensive intrusive igneous complexes both in subsurface data and in field studies has resulted in quantification of the volumes of igneous material. Despite this research there is still little connection established between the amount of igneous material intruded into a basin and its effect on subsequent basin evolution in terms of burial and loading. To understand how additional igneous material may influence basin evolution we investigate igneous intrusions from the FaroeShetland Basin (FSB) utilising subsurface data. This study highlights that the total estimated thickness of sediment during Cretaceous is likely an overestimate as the sedimentary fill consists of significant quantities of igneous material which was emplaced during the Paleocene (56-54 Ma).

Previously this additional igneous material has not been accounted for in estimates of sedimentation rates and the burial history of the FSB. Importantly petroleum system modelling to understand generation and expulsion of hydrocarbons benefits from correct estimates of basin fill. The overthickening of basins by igneous material will affect the timing of hydrocarbon generation and subsequently the proper evaluation of exploration targets. In order to fully understand basin evolution the volumes of igneous material and when this material was emplaced must be acknowledged and considered. 
Research of igneous intrusion and magma movement within the shallow crust has benefited greatly in recent years from the utilisation of three dimensional (3D) seismic reflection datasets acquired for hydrocarbon exploration. These datasets have allowed for detailed analysis of basins with igneous intrusions globally, with studies identifying emplacement mechanisms, intrusion morphologies and the impacts of the intrusions on hydrocarbon exploration (Davies et al. 2002; Smallwood \& Maresh 2002; Thomson and Hutton 2004; Planke et al. 2005; Archer et al. 2005; Holford et al. 2013; Schofield et al. 2015; Mark et al. 2017). Recent studies have focused on marrying field observations with subsurface data which has broadened the understanding of intrusive igneous processes (Schofield et al., 20I2a, Eide et al., 2017a; Eide et al. 20I7b). Commonly research into igneous intrusions has attempted to determine the total volume of the intrusive material by using subsurface data and also field based studies (Smallwood \& Maresh 2002; Svensen et al. 2012; Richardson et al. 2015; Reynolds et al. 20I8). By determining the total volumes of intrusive igneous material, researchers have attempted to predict factors such as extrusive effusion rates, mechanisms driving volcanism, dimensions of shallow magma chambers and intrusive to extrusive ratios (Ellwood \& Watkins 1976; White et al. 2006; Valentine \& Perry, 2007; Ferguson et al. 2010; Richardson et al. 20I5; Reynolds et al. 2018).

Previous studies from other basins with significant intrusive igneous material have estimated, using a variety of methods, the total volumes of intrusive igneous material. The Karoo Basin, South Africa is estimated to contain $340,000 \mathrm{~km}^{3}$ of intrusive igneous material based on geology maps (Svensen et al. 2012). Within the Northern Atlantic Margin, $560-780 \mathrm{~km}^{3}$ of igneous material has been revealed from deep penetration seismic profiles along the continent-ocean transition (Roberts et al. 2009). Additionally, in the Bight Basin, Southern Australia, $92-1 \mathrm{II} \mathrm{km}^{3}$ of intrusive igneous material was calculated from seismic mapping of 3D seismic data (Reynolds et al. 2018).

Although it has been observed that the emplacement of igneous intrusions into a sedimentary basin can result in localised forced folding of the overburden, host rock deformation and compartmentalisation of sediments (Gibb \& Kanaris-Sotiriou 1988; Bell \& Butcher 2002; Archer et al. 2005; Thomson \& Schofield 2008; Schofield et al. 20I5; Magee et al. 2016; Grove et al. 20I7; Senger et al. 2017), the critical link between magmatic intrusion into a sedimentary basin and the implication for 
a basin's evolution has yet to be made. Recent work in basins with extensive igneous intrusions has also highlighted problems related to understanding what igneous material is not being seismically imaged in the subsurface due to issues such as the vertical resolution of both well and seismic data (Schofield et al. 2015; Eide et al. 20I7b; Mark et al. 20I7). Work by Schofield et al. (2015) and Mark et al. (2017) revealed that $>80 \%$ of the intrusions within the Faroe-Shetland Basin (FSB) (and likely other basins globally) would not be imaged due to the igneous intrusions being of a thickness significantly below that needed to resolve in seismic reflection data.

To evaluate the impact of this additional igneous material on basin evolution we have interpreted I43 igneous intrusions in 3D seismic datasets from the FSB and estimated the thickness and total volume of intrusive material (Fig. I). The major findings of this work are: : (I) the total volume of mafic intrusive igneous material within the study ranges from a minimum of $399 \mathrm{~km}^{3}$ to a maximum estimate of $2,300 \mathrm{~km}^{3} ;(2)$ the distribution of this additional igneous material is highly varied across the FSB, and ranges from $20 \mathrm{~m}$ (Southern Flett sub-basin) to over $1.8 \mathrm{~km}$ (Nuevo sub-basin); (3) critically, the additional igneous material has resulted in an overestimation of sedimentary thickness across large areas of the FSB; (4) basin modelling for the FSB should compensate for the over thickening of the sedimentary fill by igneous material during sediment deposition and incorporate it at the appropriate time.

We believe that these insights present a vital methodology to fully understand how significant volumetric input of intrusive igneous material can impact estimations of the scale of magmatic activity, sedimentation rate and the general basin evolution.

\section{GEOLOGICAL HISTORY}

The FSB is located between the Faroe and Shetland Islands on the Atlantic passive continental margin of NW Europe (Fig. I). The basin can be sub-divided into a series of SW-NE trending sub-basins and is bound by the Rockall Trough to the SW and the Møre Basin to the NE (Hitchen \& Ritchie 1987). The sub-basins consist of Mesozoic to Recent sediments bounded by basement highs comprised of Precambrian crystalline rocks capped by Palaeozoic and Mesozoic sediments (Lamers \& Carmichael 
1999). The FSB has undergone several stages of rifting between the Devonian and Paleocene, followed by Cenozoic episodes of inversion (Smallwood \& Maresh 2002; Ritchie et al. 201I; Ellis \& Stoker, 2014).

The FSB, along with the NE Atlantic Margin, underwent considerable igneous activity during the late Paleocene to Early Eocene (White \& Mckenzie 1989; Jolley \& Bell 2002; Ellis \& Stoker 20I4; Hardman et al. 2018). This igneous activity resulted in expulsion of extensive extrusive basaltic sequences and the emplacement of a pervasive suite of sills and dykes, the majority of which intrude into Upper Cretaceous shales (Gibb \& Kanaris-Sotriou 1998, Bell \& Butcher 2002, Thomson \& Schofield 2008, Schofield et al. 20I5, Schofield et al. 2017). The assemblage of sills and dykes are collectively termed the Faroe-Shetland Sill Complex (FSSC) and are identified throughout the SW-NE trending sub-basins of the FSB, extending northwards into the Møre basin and southwards into the Rockall Trough (Ritchie et al. 20II; Schofield et al. 2017) (Fig. I).

\section{DATASET}

The data used within this study consists of the Faroe-Shetland PGS MegaSurvey Plus and the PGS/TGS FSB 20I I-I2 MultiClient GeoStreamer, 3D seismic datasets (Fig. Ib). The MegaSurvey Plus covers an area of $24,000 \mathrm{~km}^{2}$ and the FSB $20 \mathrm{ll}-\mathrm{I} 2$ survey covers an area of $2,662 \mathrm{~km}^{2}$. The MegaSurvey Plus data has undergone substantial reprocessing leading to improved imaging of the FSSC (Schofield et al. 2015). The FSB 20II-12 data were acquired using Geostreamer technology which records broader bandwidth than were possible with older conventional data. The preservation of lower frequencies is critical for imaging the FSSC below the extrusive basalt towards the west of the study area (Hardman et al. 2018). Both of the 3D datasets are displayed in the time domain only and are displayed at standard polarity (Sheriff \& Geldart 1995), with a downward increase in acoustic impedance corresponding to a positive amplitude (hard kick), displayed in red, and a downward decrease in acoustic impedance corresponding to a negative amplitude (soft kick), displayed in blue (Fig. 2). The igneous intrusions which were mapped across the study area were interpreted on a positive amplitude 
(red) (Fig. 2). The intrusions are readily identified as high amplitude features which are laterally discontinuous and cross-cut stratigraphy.

The well data includes all the released exploration and appraisal wells drilled in the FSB, which were analysed to identify igneous intrusions (see Mark et al. 2017). Within this dataset, 30 wells encountered intrusions with 252 penetrations of individual intrusions. For each intrusion the thickness and host rock lithology and age was recorded. The locations of the wells that encountered igneous intrusions are highlighted in Fig. I. Despite the location of some wells outside the main study area, they were still used to scale the interpreted seismic intrusive data and infer relationships that are not possible at the resolution of seismic data (see below).

\section{CALCULATING THICKNESS AND VOLUME OF IGNEOUS INTRUSIONS IN} SEISMIC DATA

Method for calculating the thickness and volume of individual intrusions

To estimate the total volume of the igneous material within the study, the area of each intrusion was first determined by seismic mapping and the area multiplied by the thickness of each igneous intrusion. With only six wells in the study area that penetrate igneous intrusions it is not possible to determine the thickness of each individual intrusion using well data, so a method to calculate thickness from seismic data had to be developed. utilise a tuning wedge model (Widess 1973; Simm \& Bacon 2014) combined with conventional depth conversion where igneous intrusions are imaged in seismic data. As specified by Smallwood \& Maresh (2002), Schofield et al. (2015), and Mark et al. (2017), the majority of intrusions in the FSB have thicknesses that result in them being imaged as tuned reflectors (where reflections from the top and base of the intrusion constructively interfere to form a single reflector/wavelet). Of the I 45 intrusions mapped in this study, only $2 \%$ are fully resolvable with a clear top and base reflector, while the remaining $98 \%$ of the mapped intrusions are imaged as tuned reflectors only (Fig. 2). For the fully resolved intrusions it is possible to map the top and base of the intrusion, and these are depth converted using a velocity of 5,500 meters per second $(\mathrm{m} / \mathrm{s})$ (determined from sonic logs in wells that 
penetrate basaltic igneous intrusions in the FSB) to calculate the thickness between the top and base intrusion surface (Fig. 3).

When an undrilled igneous intrusion is seen within seismic data as a tuned reflector, it is not possible to determine the thickness precisely. Instead the upper and lower range of the intrusion thickness can be defined. The maximum thickness of the intrusion is defined by the tuning thickness (I/4 wavelength) since above this thickness, the top and base of the intrusion would become visible as distinct seismic events, and the reflection would no longer be tuned. The minimum thickness of an intrusion has been defined here by the detection limit of the seismic data (i.e. the thickness at which the amplitude merges with the background), below which the intrusion would not be detected in the seismic data (Fig. 3). This therefore gives a maximum and minimum thickness range for intrusions represented by a tuned reflector.

To determine the tuning thickness of the data and the limit of detectability, first the frequency of the seismic data for the area of interest, and second, the depth where the intrusions occur, must be ascertained. The dominant frequency was obtained for each individual intrusion imaged in the seismic data. This allowed changes in dominant frequency, as a result depth of emplacement, differences in the overburden and different surveys, to be accounted for across the study area.

Using the dominant frequency of the seismic data close to the intrusion and the average interval velocity of the intrusions (determined from wells which encountered intrusions) the seismic wavelength is calculated using the formula, $\lambda=V / f$, $(\lambda$ : Lambda, seismic wavelength in $m)(V:$ interval velocity, in m/s), (f: seismic frequency in $\mathrm{Hz}$ ) (Widess 1973; Simm and Bacon 20l4). The limit of detectability of seismic reflection data is variously quoted as being between $\lambda / 30$ and $\lambda / 8$, and the limit of resolution is $\lambda / 4$ (Widess 1973). It is important to note that these limits are very much 'rules of thumb' and are unique to any given seismic dataset, being affected by factors such as signal to noise ratio, acquisition and processing (Eide et al. 2017b). To ascertain what tuning thickness and detectability limit to use for igneous intrusions mapped within this study we examined wells within both surveys that penetrated both thick, seismically resolvable, and thin, unimaged intrusions. 

logs and formation logs), ranging in thickness from I $\mathrm{m}$ to $48 \mathrm{~m}$. Based on the seismic data through this well, only three of these intrusions are identifiable as discrete reflectors within the seismic data (Fig. 4). These intrusions are 36, 48, and $49 \mathrm{~m}$ thick respectively. However, the 36 and $49 \mathrm{~m}$ thick intrusions are actually four closely spaced intrusions constructively interfering to produce a response (Fig. 4). The other 39 intrusions penetrated by the well are not detectable in the seismic data (Fig. 4).

This suggests that within the seismic data alone, intrusions which are below $36 \mathrm{~m}$ in thickness are not detected.

By applying the tuning wedge thickness method to intrusions detected in seismic at the location of wells which encountered igneous intrusions we can test the viability of $\lambda / 4, \lambda / 8$ and $\lambda / 30$ for assessing the thickness of intrusions in the seismic data, given we know the true and absolute intrusion thicknesses from the well logs (Fig. 4). Using well 205/IO-2B as an example, at the location of the well, the dominant frequency of the seismic data is $15.9 \mathrm{~Hz}$ in the region of the intrusion penetrations. We calculate thicknesses for the igneous intrusions between the tuning thickness $(\lambda / 4)$ as $86 \mathrm{~m}$, and seismic detectability $(\lambda / 8)$ as $43 \mathrm{~m}$ or $1 \mathrm{I} .5 \mathrm{~m}$ for $\lambda / 30$.

From these results we determined that $\lambda / 4$ for the tuning thickness and $\lambda / 8$ for the limit of detectability was the most suitable representation of what could be seen within the seismic data, as the range of thickness $\lambda / 4$ and $\lambda / 8$ calculates for the tuned reflectors (i.e. $86 \mathrm{~m}$ and $43 \mathrm{~m}$ respectively) is comparable to the true thickness of the imaged intrusions in the well (48m, 36 and $49 \mathrm{~m})$, indicating that these methods accurately predict the upper and lower range of thickness of tuned reflectors in the seismic data. (Fig. 4).

Although $\lambda / 30$ is often quoted as the limit of detectability within seismic reflection datasets (Eide et al. 20/7b), we found this would typically underestimate the thickness of the intrusions considerably, compared with its true thickness in the well (Fig. 4). In addition, the thickness estimate that $\lambda / 30$ provides would indicate that all 44 intrusions encountered by $205 / 10-2 B$ should, in theory, be detected in the seismic data, which is clearly not the case, as only three clear intrusive reflectors are visible in the seismic data (Fig. 4). This was also noted by Eide et al. (20I7b) who observed that 
even for good quality seismic data (such as that data used in this study) typical detectability limits of $\lambda / 30$ are unlikely due to factors such as signal to noise ratio and properly accounting for the complexity of the subsurface velocity model during processing.

Having assessed the suitability of the tuning wedge model it is then possible to calculate a range of thicknesses for each intrusion with $\lambda / 4$ (tuning thickness) producing a maximum estimate and $\lambda / 8$ (limit of detectability) producing a minimum estimate. This thickness calculation assumes the intrusion is one thickness in the seismic data, which is an obvious simplification, as from field observations it is known that intrusions generally thicken and thin across their full body (e.g. field outcrops of sill complexes Jameson Land, East Greenland (Eide et al. 2017a)). However, by calculating a minimum and maximum thickness we constrain this variability in intrusion thickness across the full intrusive body. The total volume of igneous material was then calculated by summing the volume of igneous material for each igneous intrusion.

\section{Scaling the data to account for intrusions below seismic resolution}

Due to the limits of vertical resolution, igneous intrusions cannot often be detected in seismic data, which can, cumulatively, account for a substantive thickness in a subsurface sedimentary sequence (Schofield et al. 20I5; Eide et al. 20I7b; Mark et al. 2017). In areas of direct well control, this is not an issue, as the unimaged intrusion thicknesses can be taken directly from well log interpretation. However, in areas where igneous intrusions are imaged on seismic reflection data but without direct well correlation, a methodology needs to be employed to take into account the thickness of seismically unimaged intrusions.

For all six wells that penetrated igneous intrusions in the study area we have determine from petrophyscial data and formation logs that there is a total thickness of $504 \mathrm{~m}$ of igneous material. Some of this material has been discounted as the 205/I0-5A well encountered a $90 \mathrm{~m}$ thick silicic igneous intrusion which is not representative of the main FSSC, the majority of which consists of basaltic material (Mark et al, 2017). The total thickness of igneous material is therefore $414 \mathrm{~m}$, of this, $177 \mathrm{~m}$ of this material is seismically resolvable. The remaining $237 \mathrm{~m}$ is not detected in the seismic 
data, which gives a ratio of 1:1.4 for the amount of seismically detectable igneous material to undetected igneous material. Figure 5 determines how we determined this ratio using the example of the 205/I0-2B well, which was then applied to all the wells that encountered igneous intrusions within the study area. By using this relationship it could be argued that, for example, for a given $50 \mathrm{~m}$ thick intrusion there is potentially another 70 m cumulative thickness of undetected intrusive material, in the form of numerous <I-I0's m thick sills. Figure 6 demonstrates the application of the I:I.4 ratio obtained from the well data to regions with no well penetrations to constrain how much igneous material is potentially missing in the seismic data (Fig. 6).

\section{RESULTS}

Overview of igneous intrusions in the study area

The mapped intrusions have an aerial extent of $10,500 \mathrm{~km}^{2}$. In total, 145 individual igneous intrusions were interpreted across the study area (Fig. 7), with individual intrusion areas ranging from $1 \mathrm{~km}^{2}$ to I,000 $\mathrm{km}^{2}$. The majority of the mapped intrusions are hosted within the Upper Cretaceous (III intrusions out of a total of 145 intrusions, 76.5\%). Of the remaining 34 intrusions, 19 occur in the Lower Cretaceous (13.1\%), 12 in the lower Paleocene (8.2\%) and the remaining three in the Upper Jurassic (2\%). The dominance of intrusions into Cretaceous strata versus Paleocene strata is clear, due to the preferential exploitation of argillaceous sequences (Mark et al. 20I7). However, it should be noted that due to the degradation in seismic quality below the Cretaceous sequences caused by the numerous intrusions, the apparent drop in intrusion frequency in older strata (e.g. Jurassic) is potentially a function of attenuation and a reduction in seismic bandwidth and the signal to noise ratio of the data.

Across the study area, the majority of intrusions can be seen to occur within sub-basins, with the greatest proportion of the intrusions seen within the Nuevo and Flett sub-basins, where heavily intruded Upper Cretaceous sections are observable (Fig. 7). The basinal highs typically have fewer igneous intrusions. The Flett and Rona Ridges have abundant igneous intrusions, through sections, likely due to their proximity to major bounding faults and lineaments (Schofield et al. 20I5). 
247 Importantly, the wells that penetrated igneous intrusions were drilled on the basinal highs, and have

248 fewer numbers of igneous intrusions than the basins, based on seismic observations.

The morphology of the mapped intrusions is variable, with the majority of the intrusions having a saucer-shaped morphology, similar to those outlined in Smallwood \& Maresh (2002) and Bell \&

Butcher (2002). However, in the Nuevo sub-basin (Fig. 7) the intrusion morphologies bifurcate and interconnect, crosscutting the host rock stratigraphy, similar to the chaotic morphologies described onshore Greenland by Eide et al. (2017a).

Thickness and Volume Estimates for Imaged Igneous Intrusions

Using seismically imaged intrusions alone, thicknesses for I 45 igneous intrusions were calculated. The average thickness of all the intrusions in the study area for the maximum $(\lambda / 4)$ and minimum estimate $(\lambda / 8)$ is $92 \mathrm{~m}$ and $42 \mathrm{~m}$ respectively (Fig. 7). Based on these thickness estimates, apparent thickness maps (isopach) for every mapped intrusion have been created across the full study area, which show the cumulative thickness of igneous intrusive material for the minimum and maximum scenarios (Fig. 7). basins where the cumulative thicknesses of imaged igneous material can be as great as $850 \mathrm{~m}$, taking the maximum thickness estimates $(\lambda / 4)$, and as little as $500 \mathrm{~m}$ using the minimum estimate $(\lambda / 8)($ Fig. 7). In other regions of the study area where no intrusions have been imaged the cumulative thickness maps show no igneous material. However, undetectable sills are likely to be present in these areas (Fig. 7).

For the volume of igneous material for each mapped igneous intrusion, we determined a range of volumes based on the maximum $(\lambda / 4)$ and minimum $(\lambda / 8)$ thickness estimates. For the maximum $(\lambda / 4)$ thickness estimate the volumes of the individual igneous intrusions ranges from $205 \mathrm{~km}^{3}$ to 0.05 $\mathrm{km}^{3}$ with an average volume of $6 \mathrm{~km}^{3}$. For the minimum $(\lambda / 8)$, thickness estimate the volumes of the

272 individual igneous intrusions ranges from $4 \mathrm{I} \mathrm{km}$ to $0.02 \mathrm{~km}^{3}$ with and average volume of $2 \mathrm{~km}^{3}$. It is worth noting that the upper ranges of thickness and volume is skewed by one anomalously thick and 
laterally extensive igneous intrusion in the north of the study area which has an individual area of 1,002 $\mathrm{km}^{2}$, but is potentially much larger as its total extent is outside of the study area. The cumulative volume of all the igneous material across the study area when taking the maximum and minimum thickness estimates ranges from $399-925 \mathrm{~km}^{3}$.

Thickness and volume estimates for imaged \& the addition of unimaged igneous intrusions Although the thickness and volume ranges calculated in the previous section can give a first order approximation of igneous material within the FSB, they do not, as discussed in the methodology section, take into account the thickness (and volume) of seismically undetectable igneous intrusions. Using the ratio of I:I.4 of imaged to unimaged intrusions, we have also created thickness maps which show the cumulative thickness of intrusive igneous material, similar to the maps outlined above, but scaled to account for unimaged igneous material (Fig. 7). For these cumulative thickness maps in areas with multiple stacked intrusions, such as the Nuevo sub-basin, the cumulative thickness of igneous material is as great as $850 \mathrm{~m}$ based on the mapped visible intrusions, however taking into account unimaged intrusions our study implies there is potentially cumulative thicknesses of $2,000 \mathrm{~m}$ (Fig. 7). Figure 8 shows the intrusion thickness maps in the context of the basin structure demonstrating the greater abundance of igneous intrusions in region such as the Nuevo sub-basin (Fig. 8).

We have also determined a range of volumes based on the maximum $(\lambda / 4)$ and minimum $(\lambda / 8)$ thickness estimates including the addition of the unimaged intrusions. The cumulative volume the igneous material across the study area, taking the maximum and minimum thickness estimates plus the addition of seismically unimaged igneous material, ranges from $957-2,220 \mathrm{~km}^{3}$.

\section{DISCUSSION}

Accounting for the underestimations of igneous material

The cumulative thickness and volume of igneous material discussed is based on the mapping of intrusions in seismic data and scaling this to account for the thin intrusions that cannot be detected in 
seismic data. Utilising well logs to calibrate seismic interpretations across the study area our method provides a good estimate of the range of igneous material thicknesses and volumes but it is still likely to underestimate the total volume of igneous material within the basin due to factors such as vertical to sub-vertical intrusions and intrusions with variable compositions (e.g. lower acoustic impedance silicic intrusions).

The intrusions that have been mapped across the study area are all identified as horizontal to sub-horizontal features, classifying them as sills. Vertical features, such as igneous dykes, are inherently difficult to image in seismic data. However, field observations from other basins with igneous intrusions imply ratios of sills to dykes of I:166 (San Rafael, south west Utah, San Rafael Intrusive Complex (Kyosugi et al. 2012)) to I:3 (lower Paleogene intrusive complex on Jameson Land, East Greenland (Eide et al. 2017a)). The type of intrusion morphology is largely controlled by the tectonic regime, therefore extensional basins are commonly associated with vertical features such as dykes. Although these studies demonstrate that dykes are more abundant than sills, the dykes tend to be much thinner and thus account for lower volumes of igneous material.

Mark et al. (2017) demonstrated in a study from the FSB that, based on well and seismic data that there are rare occurrences of silicic intrusions ( $<10 \%$ based on well penetrations). These may be underrepresented due to their lower density and compressional sonic velocities when compared to mafic intrusions, meaning they are hard to image in seismic and well data (Mark et al. 2017). These silicic igneous intrusions would result in additional igneous material, which cannot be accounted for, further underestimating the amount of igneous material in the basin.

\section{Comparison of total volume of intrusive material to previous estimates}

Estimating the volume of igneous material in a basin has importance for understanding the magma productivity through time, deep mantle activity and even climactic drivers (White \& Mckenzie 1989; Storey et al. 2007; Aarnes et al. 20I0). To test the validity of the methodology and the values we have calculated, we compare this study's volume of igneous material to previous work looking at the range of volume of igneous material in a basin. Previous estimates of the total volume of igneous material in 
the North Atlantic Igneous Province (NAIP) range from 5-10 x 106 km³, (White \& Mckenzie 1989;

Eldholm \& Grue 1994; Holbrook et al. 200I) which includes both extrusive and intrusive volcanism in the FSB, Rockall, Møre and Vøring Basins and Greenland region (area of $1.3 \times 10^{6} \mathrm{~km}^{2}$, Eldholm \& Grue 1994). These studies calculated their volumes based on limited 2D seismic transects across the NAIP margins and sparse well data obtained from the Ocean Drilling Program (ODP) (White \& Mckenzie 1989; Eldholm \& Grue 1994; Holbrook et al. 200I). The total volume of igneous material across this $10,500 \mathrm{~km}^{2}$ study area ranges from $399 \mathrm{~km}^{3}$ to $2,405 \mathrm{~km}^{3}$ including the minimum and maximum scaled thickness data. Scaling the volume of intrusive igneous material calculated in this study to the same area of the total NAIP from Eldholm \& Grue (1994) produces volumes ranging from $4.9 \times 10^{4}$ to 2.9 $\times 10^{5} \mathrm{~km}^{3}$. Despite our lower estimate than the previous work it is likely more accurate given that it is linked to well data and previous studies were dependant on limited well data and sparse 2D seismic data.

This study, when compared with research that also primarily focuses on the intrusive igneous material volumes using a similar seismic method have comparable values for the volume of intrusive igneous material. The study by Reynolds et al. (2018) for the Bight Basin, Australia, used a similar technique and resulted in igneous volumes of $92-1 \mathrm{II} \mathrm{km}^{3}$ which are comparable considering the scale of the study and number of intrusions in the study area, indicating that the technique also applied in this study is producing valid volume estimates of igneous material. Planke et al. (2005) similarly estimated the volume of intrusive igneous material from seismic data in the Vøring and Møre basins, which contains an extension of the FSSC into the Norwegian Margin estimating study the volume of intrusive igneous material to be in the region of $0.9 \times 10^{4}$ to $2.8 \times 10^{4} \mathrm{~km}^{3}$ for an area of $80,000 \mathrm{~km}^{2}$. Scaling the data from this study to the same area as the Vøring and Møre Basins study results in a cumulative volume of igneous material ranging from $3.0 \times 10^{3}$ to $1.8 \times 10^{4} \mathrm{~km}^{3}$. The volumes are considerably higher than the calculated volumes from the FSB study presented here, when scaled to the same area as the Vøring and Møre basin study (Planke et al. 2005). This difference is potentially due to differences in the techniques used to estimate the volumes in both studies. Planke et al. (2005) calculated the volume by taking the areal extent of the intrusions and then multiplying this by the 
thickness of the intruded basin. This technique captures a range of volumes, but is likely an overestimation due to oversimplification, compared to calculating the volume of each mapped intrusion as demonstrated in this study.

\section{Magma accommodation in sedimentary basins: localized host rock deformation vs I:I uplift}

The intrusion of magma into sedimentary sequences introduces a volume of material which needs to be accommodated in the subsurface rock mass. When magma is emplaced into clastic rocks that are not fully consolidated or cemented by diagenesis and still retain porosity, much of the volume of magma added can be accommodated by localized host rock deformation mechanisms such as porespace collapse, expulsion of pore fluids and mechanical compaction (Schofield et al. 2012b). Any resulting volume that cannot be solely accommodated by these means, is often accommodated by uplift of the overburden above the intrusion (Einsele et al. 1980; Jackson et al. 2013; Schofield et al. 20I2b; Magee et al. 20I3) (Fig. 9).

However, if magma emplacement occurs deeper within a sedimentary basin, where host rocks are compacted and cemented, the host rock that the magma is intruding into will possess little to no ability to accommodate the volume of the magma by localized host rock deformation. In this circumstance, the additional magma volume added can only be accommodated by uplift/and or faulting of overlying rock on a I:I basis (Hutton 2009; Jerram et al. 20I0; Eide et al. 20I7a) (Fig. 9).

This theoretically implies, that given a series of intrusions, emplaced at the same time at different depths vertically within a basin, differential vertical uplift will occur. Deep seated intrusions will jack up the overlying host rock by equal amounts to their thickness (see Eide et al. 20I7a), but at shallow basin levels, a certain degree of magma volume could be accommodated by localised host rock deformation, a mechanism termed 'differential vertical intrusion-induced uplift' by Eide et al. 20I7a.

The exact transition depth where the host rock becomes incapable of deforming to accommodate magmatic intrusions on a localised scale is difficult to estimate. However, the dominant mechanical mechanism whereby emplacement of magma can be accommodated locally is likely via collapse of any available pore space. 

dehydration and compaction, resulting in the re-arrangement of individual grains and resulting collapse of pore space and by chemical dissolution at grain contacts (Allen \& Allen 20I3). Within shales, porosity drops rapidly, so that a shale with an initial porosity of $\sim 60 \%$ at $0 \mathrm{~m}$, under normal burial conditions, by $2 \mathrm{~km}$ burial will have approximately $\sim 5-25 \%$ porosity, and by $4 \mathrm{~km}$ the porosity will have dropped to $15 \%$ or lower (Allen \& Allen 20I3). It is worth noting that porosity values for shales when derived from petrophyscial logs are influenced by the bound water which can calculate higher porosity values. Within sandstones, the depositional porosity typically ranges from $39-49 \%$, however at 2-3 km, porosity reduces to I5-25\% (Pryor 1973; Allen \& Allen 20I3). During intrusion, a host rock's ability to deform to accommodate a volume of magma will also be largely controlled by the ability to compact the host rock and cause further porosity reduction on a local scale (Schofield et al. 2012b; Eide et al. 2017a). For example, a $50 \mathrm{~m}$ intrusion intruded at relatively shallow level of $500 \mathrm{~m}$ below the paleo-surface in a predominantly claystone dominated sequence, will be intruding into a host rock of $\sim 30-40 \%$ porosity, and therefore, a maximum $20 \mathrm{~m}$ of the $50 \mathrm{~m}$ thick intrusion could be accommodated by porosity reduction. For the same $50 \mathrm{~m}$ thick intrusion intruded at $\sim 5.5 \mathrm{~km}$ depth, the porosity of the host rock, if it has gone through normal compaction, will be in the region of $5-10 \%$ with only $\sim 2.5 \mathrm{~m}$ vertical thickness of the $50 \mathrm{~m}$ thick intrusion accommodated via host rock compaction. Sandstones typically preserve porosity to greater depths (Gluyas \& Cade 1997; Allen \& Allen 2003) indicating a higher proportion of igneous intrusion accommodation will occur via localised host rock deformation. However, contradictory to this, recent work by Grove (2014) has shown that porosity reduction in sandstones surrounding igneous intrusions is minor and the effects were detected at a maximum of $4 \mathrm{~m}$ from the igneous intrusion, indicating 406 that even in porous sandstones local deformation processes will only account for a minor amount of intrusion accommodation. By calculating the paleo-depth of emplacement for the igneous intrusions in the study area we can determine if host rock deformation or I:I uplift is the more dominant process, which is important for understanding how the additional igneous material influences basin evolution. 

decompaction to calculate the paleo-depth of emplacement for the igneous intrusions across the study area and compare this with compaction curves for the host rock sediments. If the porosity of the host rock sediments is significantly reduced, the ability for the intrusion to be accommodated by host rock deformation is less and I:I uplift of the host rock would be the favoured mechanism. To calculate this, we use porosity depth trends for shales (Fig. I0) as opposed to sandstones as the majority of the FSSC intrusions are emplaced into the Upper Cretaceous. This unit is composed of thick shale sequences, and from the well data, $97 \%$ of the intrusions penetrated by wells in the Upper Cretaceous are hosted within shale sequences (Mark et al. 2017) (Fig. 10).

To determine the paleo-depth of emplacement we utilised a methodology from Smallwood \& Maresh (2008) and the decompaction method from Hardman et al. (2018). This process begins with back stripping the sediments which were deposited post 56.I Ma using the age determination of the emplacement of FSSC (Schofield et al. 2015), before decompacting all the sediments that occur above the average depth at which the intrusions occur in seismic at the time of emplacement. This gives average paleo-depths of emplacement of $867 \mathrm{~m}$ for the lower Paleocene hosted intrusions, $2,52 \mathrm{I} \mathrm{m}$ Specifically, at the paleo-depth of $867 \mathrm{~m}$ for emplacement of the lower Paleocene hosted intrusions the host rock porosity is expected to be $12-45 \%$, for the Upper Cretaceous hosted intrusions at 2,52 I $\mathrm{m}$ the host rock porosity would be $4-25 \%$ and for Lower Cretaceous hosted intrusions the host rock porosity would be $3-18 \%$. At paleo-depths of $\sim 2,500 \mathrm{~m}$ where a large majority of the intrusions occur, the porosity of shale would be $<10 \%$, indicating that accommodation via host rock deformation would have been minimal (Fig. I0). Based on the calculation of the paleo-depth of emplacement we determine that, little to none $(<10 \%)$ of the intruded igneous volume within the study area would have been able to be accommodated by localized host rock deformation processes. Therefore the emplacement of 
magma must have been accommodated by uplift and thickening of the sequences into which they intruded, as per the mechanism proposed by Eide et al. (2017a).

Overestimation of the Cretaceous sedimentary fill due to igneous intrusions

441 If magma intruding into a basin cannot be accommodated by localized host rock deformation, this may create a somewhat geologically unique scenario where a sedimentary unit or sequence can become artificially thickened ('overthickened') post-deposition as a result of intrusion of large volumes of igneous intrusions (Schofield et al. 2017). This means that the present day thickness of sedimentary sequences (e.g. Cretaceous) as mapped and ascertained from seismic data across a heavily intruded sedimentary section, will appear to be thicker than originally deposited. In such a circumstance, to determine the true thickness of the sedimentary unit prior to intrusion, the thickness of the intrusions needs to be removed (Fig. II \& I2) and the sedimentary section 'de-silled'

Within the study area, the total thickness of the Cretaceous based on seismic mapping varies from $3,113 \mathrm{~m}$ in the basinal areas to $16 \mathrm{I} \mathrm{m}$ on the structural highs, with an average thickness of $2,49 \mathrm{I}$ $\mathrm{m}$. Other studies looking at the Cretaceous across the FSB have a range of thicknesses from 4.5 to 5 km of sediment (Lamers \& Carmichael 1999; Stoker 2016). However, when the igneous material is removed from the Cretaceous, reconstructing it to its true thickness prior to the emplacement of the FSSC, the Cretaceous sedimentary sequence becomes much thinner. For example, in the Nuevo subbasin, the Cretaceous sequence ranges from 2,883 to $3,672 \mathrm{~m}$, removing the cumulative igneous material would result in a Cretaceous which is up to I,500 m thinner.

It is important to note that the thickness of the igneous material is not uniform across the study area, with some regions having considerably more igneous material, even across relatively short distances. For example the Nuevo sub-basin is heavily intruded in comparison to the Cambo High, only $2 \mathrm{~km}$ away (Fig. 8). This spatially non-uniform nature of intrusion thickness in sub-basins is likely the result of the magma input zones as highlighted by Schofield et al. (2015). This work also shows that proximity to half-graben bounding faults results in greater number of intrusions, as these bounding faults are acting as magma conduits for deep input into the basin. The Nuevo sub-basin is the most 
heavily intruded sub-basin in the FSB due to a major Cretaceous-Paleocene fault on the south of the Corona Ridge (Fig. 8). This major fault was likely a long-lived magma conduit transferring vast amounts of igneous material into the Nuevo Sub-basin. The difference in the abundance of igneous material across the basin is important to consider as it implies that each sub-basin has a different evolution through time and therefore must treated individually.

Recognition of the potential for a much thinner Cretaceous sequence has some major implications. In particular it suggests that previous estimations of sedimentation rates in the FSB, particularly for the Cretaceous, have been overestimated in areas. Acknowledging that sedimentation rates are much lower during the Cretaceous is essential for understanding the development of Cretaceous phases of rifting along the North Atlantic Margin. Stoker (2016) documents thick accumulations of sediments in the Upper Cretaceous for the Judd (I,583 $\mathrm{m})$ and Flett sub-basins $(3,7 / 9$ $m$ ) as evidence of the magnitude of rifting during this period. We note that the time period of the Upper Cretaceous inferred by Stoker (2016) to having the thickest sedimentary sequence and highest sedimentation rates is also the most heavily intruded stratigraphy. Stoker (2016) calculates the sedimentation rate of $73.9 \mathrm{~m} \mathrm{Ma}$ ' within the Flett sub-basin, based on a thickness of $2,55 \mathrm{I} \mathrm{m}$ of sediment in the Upper Cretaceous. However, accounting for the maximum thickness of igneous material in the Upper Cretaceous from this study, the true thickness of the Upper Cretaceous that Stoker (2016) based calculations on could be up to $800 \mathrm{~m}$ thinner, leading to a downward revision of sedimentation rates of $51.3 \mathrm{~m} \mathrm{Ma}^{-1}$. Importantly, to correctly estimate sedimentation rates in FSB, heavily intruded sections necessitate correction for the abundant igneous intrusions (de-sill). A further important aspect of the overthickening of the sedimentary sequence by the igneous intrusions would be to understand the uplift effect of the numerous igneous intrusions. There are numerous uplift related unconformities during the Paleocene to Eocene across the FSB which could be related to the uplift associated with the emplacement of these igneous intrusions (Ritchie et al. 20I I). 
A critical part of hydrocarbon exploration and petroleum system analysis (PSA) is burial history modelling to determine when source rocks generate and expel hydrocarbons (Magoon \& Dow 1994). Generation modelling in the FSB has proven problematic as current models indicate that the primary source rock, the Upper Jurassic Kimmerridge Clay Formation (KCF) is post-mature for hydrocarbon generation in the main basinal regions of the FSB and peak generation preceded the deposition of the proven Paleocene reservoirs and trap formation (Scotchman et al. 2006). Penetrations on the basin highs such as the Corona Ridge have identified KCF sediments which are immature, but within the basinal areas these are deeply buried. (Scotchman et al. 2006). Previous research has evoked different models to account for this discrepancy. Dore et al. (1997) and Lamers \& Carmichael (1999) describe the peak generation occurring in the late Cretaceous, with early Cretaceous sandstones acting as paleo-accumulations of hydrocarbons before later migration into the Paleogene reservoirs. This theory is known as the "Motel Model". Alternatively, Scotchman et al. (2006) argued that the misalignment between hydrocarbon generation and deposition of the reservoirs is due to maturation retardation by overpressures. Both the motel model and the overpressure model invoke an offset between the onset of hydrocarbon generation and the timing of charge into Paleogene reservoirs, but the processes apply to limited geographical areas and are not applicable to the whole basin. been placed on the direct heating effect that intrusions could have on organic rich sediments and how this could result in local generation of hydrocarbons through direct kerogen cracking (Clayton \& Bostick 1985; Bishop \& Abbot 1995; Aarnes et al. 20I I; Muirhead et al. 2017). It has often been shown that maturity trends are locally elevated in the host rock surrounding igneous intrusions due the high emplacement temperatures $\left(>1,000{ }^{\circ} \mathrm{C}\right.$ for mafic intrusions), often resulting in early generation of hydrocarbons if emplaced within organic-rich shales. However, what has not been considered is the direct thickening and loading effects that the addition of intrusions rapidly overthickening a sequence can have on basin modelling and, in particular, the point at which underlying source rocks begin to generate and expel hydrocarbons. 
517 is required. We have demonstrated that the total thickness of igneous material in the Cretaceous and 518 lower Paleocene can be as great as $>2 \mathrm{~km}$ in some parts of the study area. The intrusions could result 519 in overestimation of the implied Cretaceous sedimentation rates and thus overburden thickness, which 520 is the key control influencing source maturation. In the Nuevo sub-basin, where the thickest accumulation of intrusions occurs, the mapped thickness of the Cretaceous is $4.5 \mathrm{~km}$ but with as much as $2 \mathrm{~km}$ of igneous material. This is critical for basin modelling, as a thicker Cretaceous and lower Paleocene at the time of deposition will result in greater burial of the underlying KCF source rock and therefore earlier onset of hydrocarbon generation. Alternatively, if one restores the basin to its true thickness at the time of deposition, prior to emplacement of intrusions, the onset of generation could occur later. Future hydrocarbon generation modelling across the whole of the Atlantic Margin (and over global basins) should fully account for overthickening, including the greater thickness of igneous material in the basinal areas.

\section{CONCLUSIONS}

This study demonstrates that with 3D seismic data it is possible to estimate the thickness of igneous intrusions and estimate the total volume of igneous material in a basin. By estimating the amount of intrusive igneous material in the basin, the findings and implications for basin evolution can be summarised as follows:

- This study shows that for the FSB the cumulative thickness of igneous material within sedimentary sequences in different sub-basins can be as great as $2 \mathrm{~km}$.

- The volume of igneous material ranges from $399-22205 \mathrm{~km}^{3}$, which is comparable to similar seismic based volume estimates, but also highlights that previous studies have overestimated the volume of intrusive igneous material due to less thorough methods, than outlined in this study.

- At the paleo-depth of emplacement for the intrusions in this study, there is reduced porosity 
accommodation process for the igneous intrusions in the study area is I:I uplift of the host rocks ('Jacking-Up' structures) to accommodate the igneous intrusions.

- There is overestimation of the true depositional thickness of the Cretaceous and lower Paleocene because of the additional igneous material. This igneous material was not emplaced into these sediments until 56.5 $\mathrm{Ma}$ and has important implications for understanding sedimentation rates and rifting during the Cretaceous and lower Paleocene.

- Reconstructing the basin history to remove this igneous material ("de-sill") to get true understanding of basin evolution. Compared to previous ways that basin models have incorporated igneous intrusion this model shows that intrusions (in relation to timing) can actually change the onset of hydrocarbon generation, rather than accelerate it through direct heating effects. Application of the approach demonstrated in this study would benefit the evaluation of other basins with significant intrusive igneous material to understand the basin evolution and to recognise the petroleum generation and expulsion history of source rocks.

\section{ACKNOWLEDGEMENTS}

This study was part of a collaboration between the University of Aberdeen, Siccar Point Energy Ltd and Integrated Geochemical Interpretation (IGI). Siccar Point Energy Ltd are thanked for giving the author permission to publish. Karolina Harvie and Kevin Ward from Petrosys are thanks for their support during the mapping process of the project. The lead author's PhD is funded by JX Nippon Exploration and Production (U.K.) Limited as part of the Volcanic Margin Research Consortium Phase 

was carried out using Schlumberger Petrel software. Well log analysis was carried out using Schlumberger Techlog software. Dave Ellis and Victoria Pease are thanked for the comments which greatly improved the revisions of this paper. Well data was obtained from the UK Oil and Gas Authority (OGA) Common Data Access (CDA).

REFERENCES

578

Aarnes, I., Svensen, H., Connolly, I.A. and Podladchikov, Y.Y., 20I0. How contact metamorphism can trigger global climate changes: Modeling gas generation around igneous sills in sedimentary basins. Geochimica et Cosmochimica Acta, 74(24), pp.7I79-7I 95.

Aarnes, I., Fristad, K., Planke, S. and Svensen, H., 20II. The impact of host-rock composition on devolatilization of sedimentary rocks during contact metamorphism around mafic sheet intrusions. Geochemistry, Geophysics, Geosystems, I2(10).

Allen, P.A. and Allen, J.R., 2013. Basin analysis: Principles and application to petroleum play assessment. John Wiley \& Sons.

Archer, S.G., Bergman, S.C., Iliffe, J., Murphy, C.M. \& Thornton, M. 2005. Palaeogene igneous rocks reveal new insights into the geodynamic evolution and petroleum potential of the Rockall Trough, NE Atlantic Margin. Basin Res., I 7, I7I-20I.

Bell, B.R. \& Butcher, H. 2002. On the emplacement of sill complexes: evidence from the Faroe-Shetland Basin. In: The North Atlantic Igneous Province: Stratigraphy, Tectonic, Volcanic and Magmatic Processes (Ed. by D.W. Jolly \& B. Bell) Geol. Soc. London. Spec. Publ., 197, 307-329.

Bishop, A.N. and Abbott, G.D., 1995. Vitrinite reflectance and molecular geochemistry of Jurassic sediments: the influence of heating by Tertiary dykes (northwest Scotland). Organic Geochemistry, 22(I), Pp.I65-I77.

Clayton, I.L. and Bostick, N.H., 1986. Temperature effects on kerogen and on molecular and isotopic composition of organic matter in Pierre Shale near an igneous dike. Organic Geochemistry, IO(I-3), Pp.I35-I43.

Davies, R., Bell, B.R., Cartwright, I.A. and Shoulders, S., 2002. Three-dimensional seismic imaging of Paleogene dike-fed submarine volcanoes from the northeast Atlantic margin. Geology, 30(3), pp.223226.

Doré, A.G., Lundin, E.R., Birkeland, O., Eliassen, P.E. and Jensen, L.N., 1997. The NE Atlantic margin; implications of late Mesozoic and Cenozoic events for hydrocarbon prospectivity. Petroleum Geoscience. 3(2). pp.117-131.

Eide, C.H., Schofield, N., Jerram, D.A. and Howell, J.A., 2017a. Basin-scale architecture of deeply emplaced sill complexes: Jameson Land, East Greenland. Journal of the Geological Society, I 74(I), pp.2340.

Eide, C.H., Schofield, N., Lecomte, I., Buckley, S.J. and Howell, I.A., 20 I7b. Seismic interpretation of sill complexes in sedimentary basins: implications for the sub-sill imaging problem. Journal of the Geological Society, pp.jgs2017-096. 
Einsele, G., Gieskes, I.M., Curray, I., Moore, D.M., Aguayo, E., Aubry, M.P., Fornari, D., Guerrero, I., Kastner, M., Kelts, K. and Lyle, M., 1980. Intrusion of basaltic sills into highly porous sediments, and resulting hydrothermal activity. Nature, 283(5746), p.44I.

Eldholm, O. and Grue, K., 1994. North Atlantic volcanic margins: dimensions and production rates. Journal of Geophysical Research: Solid Earth, 99(B2), pp.2955-2968.

Ellis, D., Passey, S.R., Jolley, D.W. \& Bell, B.R. 2009. Transfer zones: the application of new geological information from the Faroe Islands applied to the offshore exploration of intra-basalt and sub-basalt strata. In: Faroe Islands Exploration Conference: Proceedings of the 2nd Conference. Annales Societatis Scientiarum, Færoensis, Supplementum (Ed. by T. Varming \& H. Ziska), 50, 174 -204.

Ellis, D. and Stoker, M.S., 20I4. The Faroe-Shetland Basin: A regional perspective from the Paleocene to the present day and its relationship to the opening of the North Atlantic Ocean. Geological Society, London, Special Publications, 397, Pp.SP397-I.

Ellwood, B.B. and Watkins, N.D., 1976. Comparison of observed intrusive to extrusive ratios in Iceland and the Troodos Massif with results of experimental emplacement mode analysis of DSDP igneous rocks. Journal of Geophysical Research, 8I(23), pp.4I52-4I56.

Ferguson, D.J., Barnie, T.D., Pyle, D.M., Oppenheimer, C., Yirgu, G., Lewi, E., Kidane, T., Carn, S. and Hamling, I., 2010. Recent rift-related volcanism in Afar, Ethiopia. Earth and Planetary Science Letters, 292(3), pp.409-4I8.

Gibb, F. \& Kanaris-sotiriou, R. 1988. The geochemistry and origin of the Faeroe-Shetland Sill Complex. In: Early Tertiary Volcanism and the Opening of the NE Atlantic (Ed. by A.C. Morton \& L.M. Parson) Geol. Soc. Lond. Spec. Publ., 39, 24I-252.

Gluyas, J. and Cade, C.A., 1997. Prediction of porosity in compacted sands.

Grove, C., 2014. Direct and indirect effects of flood basalt volcanism on reservoir quality sandstone (Doctoral dissertation, Durham University).

Grove, C., Jerram, D.A., Gluyas, J.G. and Brown, R.J., 2017. Sandstone Diagenesis in Sediment-lava Sequences: Exceptional Examples of Volcanically Driven Diagenetic Compartmentalization in Dune Valley, Huab Outliers, Nw Namibia. Journal of Sedimentary Research, 87( I2), pp. I3 I4-I 335.

Hardman, I., Schofield, N., lolley, D., Hartley, A., Holford, S. and Watson, D., 2018. Controls on the distribution of volcanism and intra-basaltic sediments in the Cambo-Rosebank region, West of Shetland. Petroleum Geoscience, pP.petgeo2017-06I.

Hitchen, K \& Ritchie, J.D. 1987. Geological review of the West of Shetland area. In: Petroleum Geology of North West Europe, Brooks, J. and Glennie, K. (eds), 1987, Graham \& Trotman, pp 737749.

Holbrook, W.S., Larsen, H.C., Korenaga, J., Dahl-Jensen, T., Reid, I.D., Kelemen, P.B., Hopper, J.R., Kent, G.M., Lizarralde, D., Bernstein, S. and Detrick, R.S., 200I. Mantle thermal structure and active upwelling during continental breakup in the North Atlantic. Earth and Planetary Science Letters, 190(3), Pp.25I-266.

Holford, S.P., Schofield, N., Jackson, C.A.-L., Magee, C., Green, P.F. \& Duddy, I.R. 20I3. Impacts of igneous intrusions on source and reservoir potential in prospective sedimentary basins along the western Australian continental margin. In: The Sedimentary Basins of Western Australia IV (Ed. by M. 
Keep \& S.J. Moss), Proceedings of the Petroleum Exploration Society of Australia Symposium, Perth, WA.

Hutton, D.H.W., 2009. Insights into magmatism in volcanic margins: bridge structures and a new mechanism of basic sill emplacement-Theron Mountains, Antarctica. Petroleum Geoscience, 15(3), Pp.269-278.

Jackson, C.A., Schofield, N. and Golenkov, B., 2013. Geometry and controls on the development of igneous sill-related forced folds: A 2-D seismic reflection case study from offshore southern Australia. Bulletin, I25(II-I2), Pp.1874-1890.

Jerram, D.A., Davis, G.R., Mock, A., Charrier, A. and Marsh, B.D., 2010. Quantifying 3D crystal populations, packing and layering in shallow intrusions: A case study from the Basement Sill, Dry Valleys, Antarctica. Geosphere, 6(5), pp.537-548.

Jolley, D.W. and Bell, B.R., 2002. The evolution of the North Atlantic Igneous Province and the opening of the NE Atlantic rift. Geological Society, London, Special Publications, 197(I), Pp. I-I3.

Kiyosugi, K., Connor, C.B., Wetmore, P.H., Ferwerda, B.P., Germa, A.M., Connor, L.J. and Hintz, A.R., 2012. Relationship between dike and volcanic conduit distribution in a highly eroded monogenetic volcanic field: San Rafael, Utah, USA. Geology, 40(8), pp.695-698.

Lamers, E. \& Carmichael, S.M.M. 1999. The Paleocene deepwater sandstone play west of Shetland. In: Petroleum Geology of Northwest Europe: Proceedings of the 5th Conference (Ed. By A.J. Fleet \& S.A.R. Boldy), Pp. 645-659. The Geological Society, London.

Magee, C., Briggs, F. and lackson, C.A., 20I3. Lithological controls on igneous intrusion-induced ground deformation. Journal of the Geological Society, I 70(6), pp.853-856.

Magee, C., Muirhead, J.D., Karvelas, A., Holford, S.P., Jackson, C.A., Bastow, I.D., Schofield, N., Stevenson, C.T., McLean, C., McCarthy, W. and Shtukert, O., 2016. Lateral magma flow in mafic sill complexes. Geosphere, I2(3), pp.809-84I.

Magoon, L.B. and Dow, W.G., 1991. The petroleum system-from source to trap. AAPG Bulletin (American Association of Petroleum Geologists);(United States), 75(CONF-910403--).

Mark, N.]., Schofield, N., Pugliese, S., Watson, D., Holford, S., Muirhead, D., Brown, R. and Healy, D., 2017. Igneous intrusions in the Faroe Shetland basin and their implications for hydrocarbon exploration; new insights from well and seismic data. Marine and Petroleum Geology.

Mudge, D. C. 2014. Regional controls on Lower Tertiary sandstone distribution in the North Sea and NE Atlantic margin basins. In: McKie, T. Rose, P. T. S. Hartley, A. J. Jones, D. W. \& Armstrong, T. L. (eds) Tertiary Deep-Marine Reservoirs of the North Sea Region. Geological Society, London, Special Publications, 403, 17-42.

Muirhead, D.K., Bowden, S.A., Parnell, I. and Schofield, N., 2017. Source rock maturation owing to igneous intrusion in rifted margin petroleum systems. Journal of the Geological Society, 0 I I.

Planke, S., Rasmussen, T., Rey, S.S. and Myklebust, R., 2005, lanuary. Seismic characteristics and distribution of volcanic intrusions and hydrothermal vent complexes in the Vøring and Møre basins. In Geological Society, London, Petroleum Geology Conference series (Vol. 6, No. I, pp. 833-844). Geological Society of London. 
Pryor, W.A., 1973. Permeability-porosity patterns and variations in some Holocene sand bodies. AAPG

Reynolds, P., Holford, S., Schofield, N. and Ross, A., 2018. The importance of subsurface lithology in controlling magma storage v. eruption: an example from offshore southern Australia. Journal of the Geological Society, PP.jgs2017-I09.

Richardson, J.A., Connor, C.B., Wetmore, P.H., Connor, L.J. and Gallant, E.A., 20I5. Role of sills in the development of volcanic fields: Insights from lidar mapping surveys of the San Rafael Swell, Utah. Geology, 43(I I), pp. I023-1026.

Ritchie, J.D., Ziska, H., Johnson, H. \& Evans, D., Eds. 20II. Geology of the Faroe-Shetland Basin and Adjacent Areas. British Geological Survey, Nottingham, UK. 317 PP (RR/I I/ 00I).

Roberts, A.W., White, R.S. and Christie, P.A.F., 2009. Imaging igneous rocks on the North Atlantic rifted continental margin. Geophysical Journal International, I 79(2), Pp. I024-I038.

Senger, K., Millett, I., Planke, S., Ogata, K., Eide, C.H., Festøy, M., Galland, O. and Jerram, D.A., 2017. Effects of igneous intrusions on the petroleum system: a review. First Break, 35(6), pp.47-56.

Schofield, N., Heaton, L., Holford, S., Archer, S., Jackson, C. \& Jolley., D.W. 20I2a. Seismic imaging of 'Broken-Bridges': linking seismic to outcrop-scale investigations of intrusive magma lobes. J. Geol. Soc., 169, $421-426$.

Schofield, N.I., Brown, D.J., Magee, C. and Stevenson, C.T., 20I2b. Sill morphology and comparison of brittle and non-brittle emplacement mechanisms. Journal of the Geological Society, I69(2), Pp. I27-I4I.

Schofield, N., Holford, S., Millet, J., Brown, D., Jolley, D., Passey, S. R., Muirhead, D., Grove, C., Magee, C., Murray, J., Hole, M., Jackson, C. A.-L. \& Stevenson, C. 20I5. Regional magma plumbing and emplacement mechanisms of the Faroe-Shetland Sill Complex: implications for magma transport and petroleum systems within sedimentary basins. Basin Research, first published online November 19, 20I5, http://doi.org//0.1 III/ bre.12164.

Schofield, N., Jolley, D., Holford, S., Archer, S., Watson, D., Hartley, A., Howell, J., Muirhead, D., Underhill, I. and Green, P., 2017. Challenges of future exploration within the UK Rockall Basin. In Geological Society, London, Petroleum Geology Conference series (Vol. 8, Pp. PGC8-37). Geological Society of London.

Scotchman, I.C., 200I. Petroleum geochemistry of the Lower and Middle lurassic in Atlantic margin basins of Ireland and the UK. Geological Society, London, Special Publications, I88(I), Pp.3I-60.

Scotchman, I.C., Carr, A.D. and Parnell, I., 2006. Hydrocarbon generation modelling in a multiple rifted and volcanic basin: a case study in the Foinaven Sub-basin, Faroe-Shetland Basin, UK Atlantic margin. Scottish Journal of Geology, 42(I), PP.I-I9.

Sheriff, R.E. and Geldart, L.P., 1995. Exploration seismology. Cambridge university press.

Simm, R. and Bacon, M., 2014. Seismic Amplitude: An interpreter's handbook. Cambridge University Press.

Smallwood, J.R. \& Maresh, J. 2002. The properties, morphology and distribution of igneous sills: modelling, borehole data and 3D seismic data from the Faeroe-Shetland area. In: The North Atlantic Igneous Province: Stratigraphy, Tectonic, Volcanic and Magmatic Processes (Ed. by D.W. Jolley \& B.R. Bell) Geol. Soc. London. Spec. Publ., 197, 27I-306. 
Sørensen, A.B., 2003. Cenozoic basin development and stratigraphy of the Faroes area. Petroleum

Stoker, M.S., 2016. Cretaceous tectonostratigraphy of the Faroe-Shetland region. Scottish Journal of Geology, 52(1), Pp.19-4I.

Storey, M., Duncan, R.A. and Tegner, C., 2007. Timing and duration of volcanism in the North Atlantic Igneous Province: implications for geodynamics and links to the Iceland hotspot. Chemical Geology, 24I(3-4), pp.264-28I.

Svensen, H., Corfu, F., Polteau, S., Hammer, $\varnothing$. and Planke, S., 2012. Rapid magma emplacement in the Karoo large igneous province. Earth and Planetary Science Letters, 325, Pp.I-9.

Thomson, K. and Hutton, D., 2004. Geometry and growth of sill complexes: insights using 3D seismic from the North Rockall Trough. Bulletin of Volcanology, 66(4), Pp.364-375.

Thomson, K. \& Schofield, N. 2008. Lithological and structural controls on the emplacement and morphology of sills in sedimentary basins, Structure and Emplacement of High-Level Magmatic Systems. Geol. Soc. Lond. Spec. Publ., 302, 3I-44.

Valentine, G.A. and Perry, F.V., 2007. Tectonically controlled, time-predictable basaltic volcanism from a lithospheric mantle source (central Basin and Range Province, USA). Earth and Planetary Science Letters, 26I(I-2), pp.20I-2I6.

White, R. \& McKenzie, D. 1989. Magmatism at Rift Zones: The Generation of Volcanic Continental Margins and Flood Basalts. Journal of Geophysical Research, 94, 7685-7729.

White, S.M., Crisp, J.A. and Spera, F.J., 2006. Long-term volumetric eruption rates and magma budgets. Geochemistry, Geophysics, Geosystems, 7(3).

Widess, M.B., 1973. How thin is a thin bed?. Geophysics, 38(6), pp. I I76-I I80.

\section{FIGURE CAPTIONS}

Figure I: a) Structural elements map of the Faroe-Shetland Basin, with outline of 3D seismic coverage used in this study, intrusions mapped in this study shown in purple and the wells that penetrated intrusions highlighted in black. b) detailed map showing the outline of the study area and the key structural features of the study area. Figure adapted from Ellis et al. 2009; Mudge 2014 and Schofield et al. 2015.

Figure 2: Seismic line from the FSB showing the typical seismic response of mafic intrusions. Mafic intrusions are characterised in seismic data as laterally discontinuous bright reflectors. Igneous intrusion imaged within the seismic line is represented by a single tuned reflector. Seismic data courtesy of PGS (FSB MegasSurvey Plus).

Figure 3: Seismic tuning wedge model demonstrating the concepts of seismic resolution and seismic detectability. $\lambda / 4$ ( $\lambda$ : lambda) represents the seismic resolution and calculates a thickness of $86 \mathrm{~m}$ base on an interval velocity of $5500 \mathrm{~m} / \mathrm{s}$ for a doleritic intrusion and a seismic frequency of $15.9 \mathrm{~Hz}$ using a Ricker wavelet.. $\lambda / 8$ calculates a thickness of $43 \mathrm{~m}$ and $\lambda / 30$ calculates a thickness of $11.5 \mathrm{~m}$. a) example of igneous intrusions from the seismic data used in this study showing the tuning effect as the intrusion becomes thinner and the top and base reflectors constructively interfere. b) wedge model and resulting seismogram, intrusion is a dolerite with an interval velocity of $5500 \mathrm{~m} / \mathrm{s}$ within a claystone with an interval velocity of $3048 \mathrm{~m} / \mathrm{s}$. c) amplitude versus wedge thickness demonstrating that as the 
top and base intrusions reflectors begin to constructively interfere, tuning occurs and the amplitude 832 increases, as the wedge becomes thinner the amplitude decreases. Seismic data is courtesy of PGS 833 (FSB MegaSurvey Plus).

834 Figure 4: a) seismic through the 205/I0-2B well showing three reflectors which represent only three 835 of the igneous intrusions encountered in the well, also shown is the well log which shows the total 44 intrusions that the well actually encountered. b) table showing the true thickness of the intrusions reflectors identified in seismic and the different methods for estimating the thickness based on the tuning wedge model. Seismic data is courtesy of PGS (FSB MegasSurvey Plus).

Figure 5: a) seismic line through the 205/ I0-2B well and lithology log of all the intrusions encountered in the well. b) logs showing the number of intrusions encountered by the well which can be imaged in seismic versus the intrusions in the well which are unresolvable in the seismic data c), this produces a relationship of I:I.6 for intrusions which can be imaged vs intrusions which are unimaged. Taking this workflow and applying it to all the wells within the study area produces a relationship of I:I.4 for intrusions which can be imaged vs intrusions which are unimaged. Using this relationship it is possible to infer the amount of additional igneous material in seismic where there is no well data. Seismic data is courtesy of PGS (FSB MegasSurvey Plus).

Figure 6: Seismic line demonstrating how it is possible to apply the 1:1.4 relationship for imaged to unimaged intrusions to regions of the study area which have no well data to constrain how much additional igneous material there is which is not detected in the seismic data. Seismic data courtesy of PGS (FSB MegasSurvey Plus).

Figure 7: a) map of the study area showing all the mapped intrusions and their thickness estimate based on $N / 4$ derived from the tuning wedge model. b) map of the study area showing all the mapped intrusions and their thickness estimate based on $\lambda / 8$ derived from the tuning wedge model. c) map of the study area showing all the mapped intrusions and their thickness estimate based on $\lambda / 4$ derived from the tuning wedge model, plus the addition of unimaged material. d) map of the study area showing all the mapped intrusions and their thickness estimate based on $\lambda / 8$ derived from the tuning wedge model. Seismic lines show the numerous stacked intrusions in the Nuevo sub-basin and Flett subbasins. Seismic data courtesy of PGS (FSB MegasSurvey Plus \& PGS/TGS FSB 2011-12 MultiClient Geostreamer).

Figure 8: Detailed structural elements map of the study area showing all the mapped intrusions and their thickness estimate based on $N / 4+$ plus the addition of unimaged material based on the well relationship. Map shows how sub-basins such as the Nuevo and Flett sub-basin are heavily intruded and generally the basinal highs have fewer intrusions.

864 Figure 9: Conceptual diagram illustrating the different mechanisms that host rocks accommodate intrusion emplacement in the subsurface. With depth ductile accommodation processes such as host rock deformation becomes less common and at depths greater than $2 \mathrm{~km}$ brittle accommodation processes are dominant, such as I:I uplift. Figure adapted from Schofield et al. 20I2b.

Figure 10: a) porosity and ability for intrusions to be accommodated via pore space collapses versus depth for shales, along with the paleo-depth of emplacement for the igneous intrusions mapped in the study area. Shale apparent porosity vs depth from Allen \& Allen (20I3). This demonstrates that for the average paleo-depth of emplacement for Upper Cretaceous hosted intrusions (UC) the porosity of the host rock would be $4-25 \%$ and with $4-25 \%$ of the intrusion thickness accommodated by pore space collapse. b) schematic demonstrating how the intrusions in the study area would be accommodated at different depths in the subsurface.

875 Figure II: Schematic illustrating the overthickening of the basin fill by igneous intrusions and the 
877 Figure 12: Digitised composite log through the 205/IO-2B well showing the 44 intrusions and their 878 cumulative thickness. Removing all this igneous material ("de-sill") to account for the overthickneing 879 results in the Cretaceous section of the well changing from $3240 \mathrm{~m}$ thick post emplacement to 2892 $880 \mathrm{~m}$ thick when the intrusions have been removed. The restoration of this section to its true thickness 881 could potentially have important implications for basin modelling. 

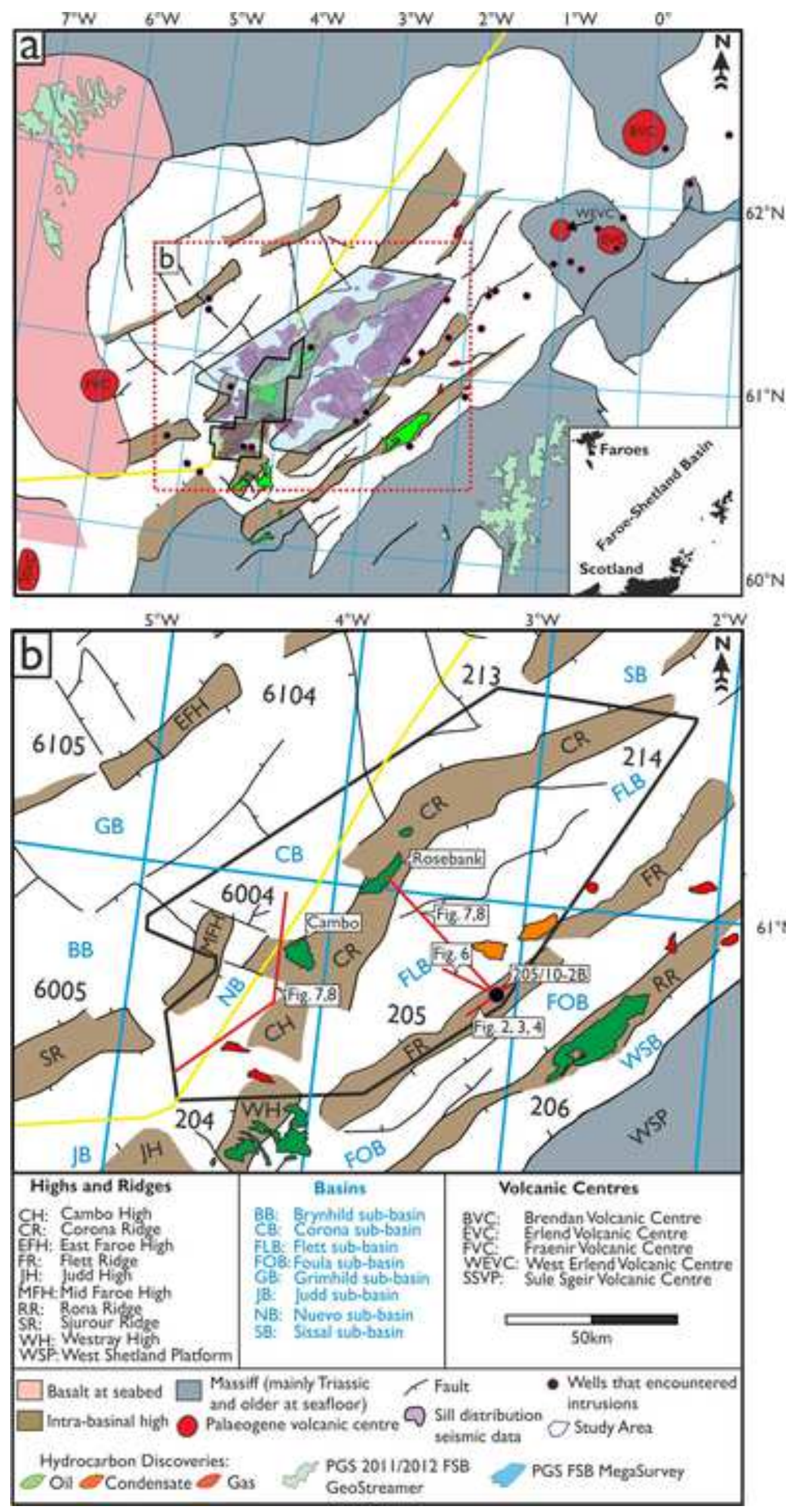


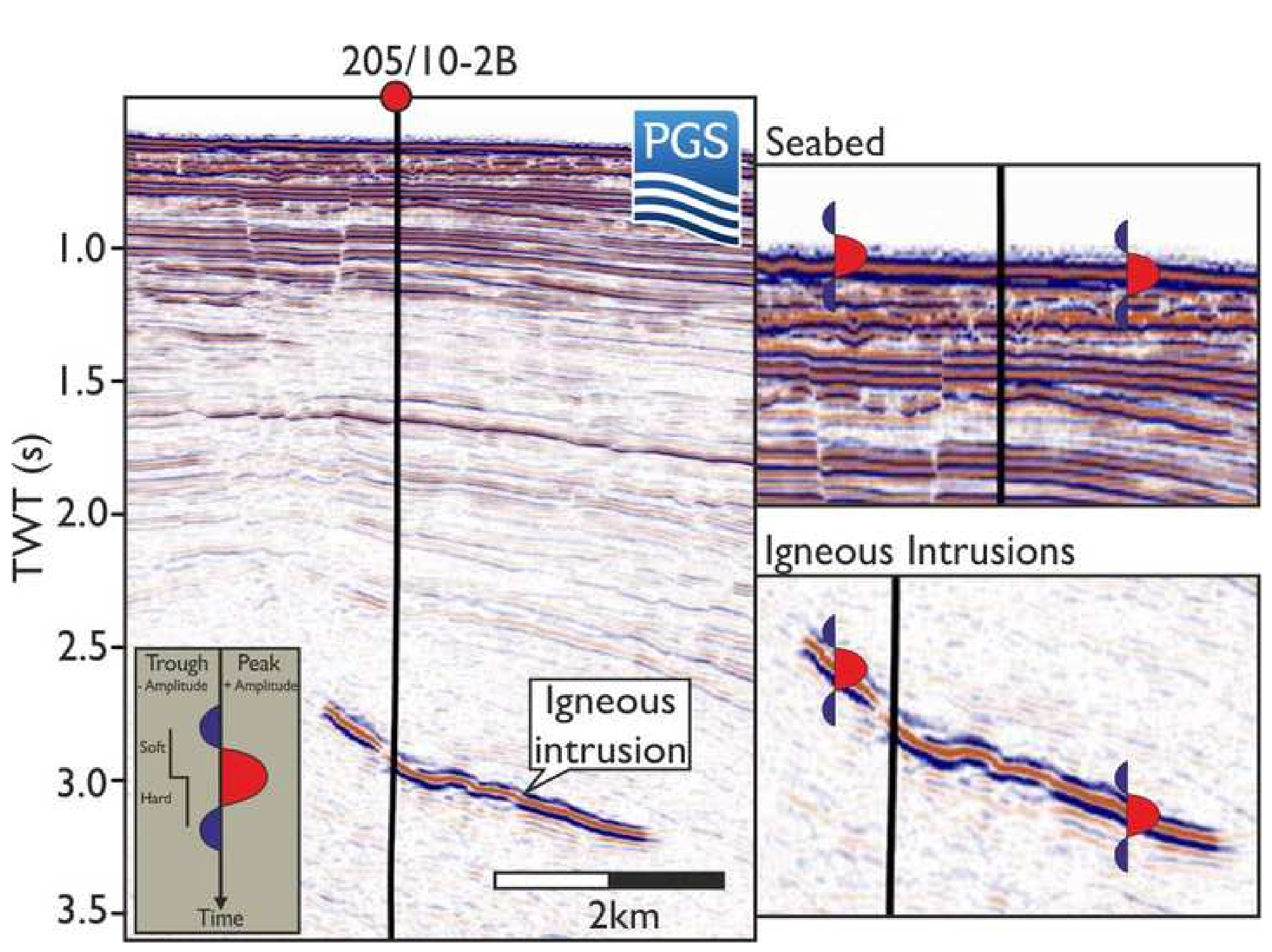



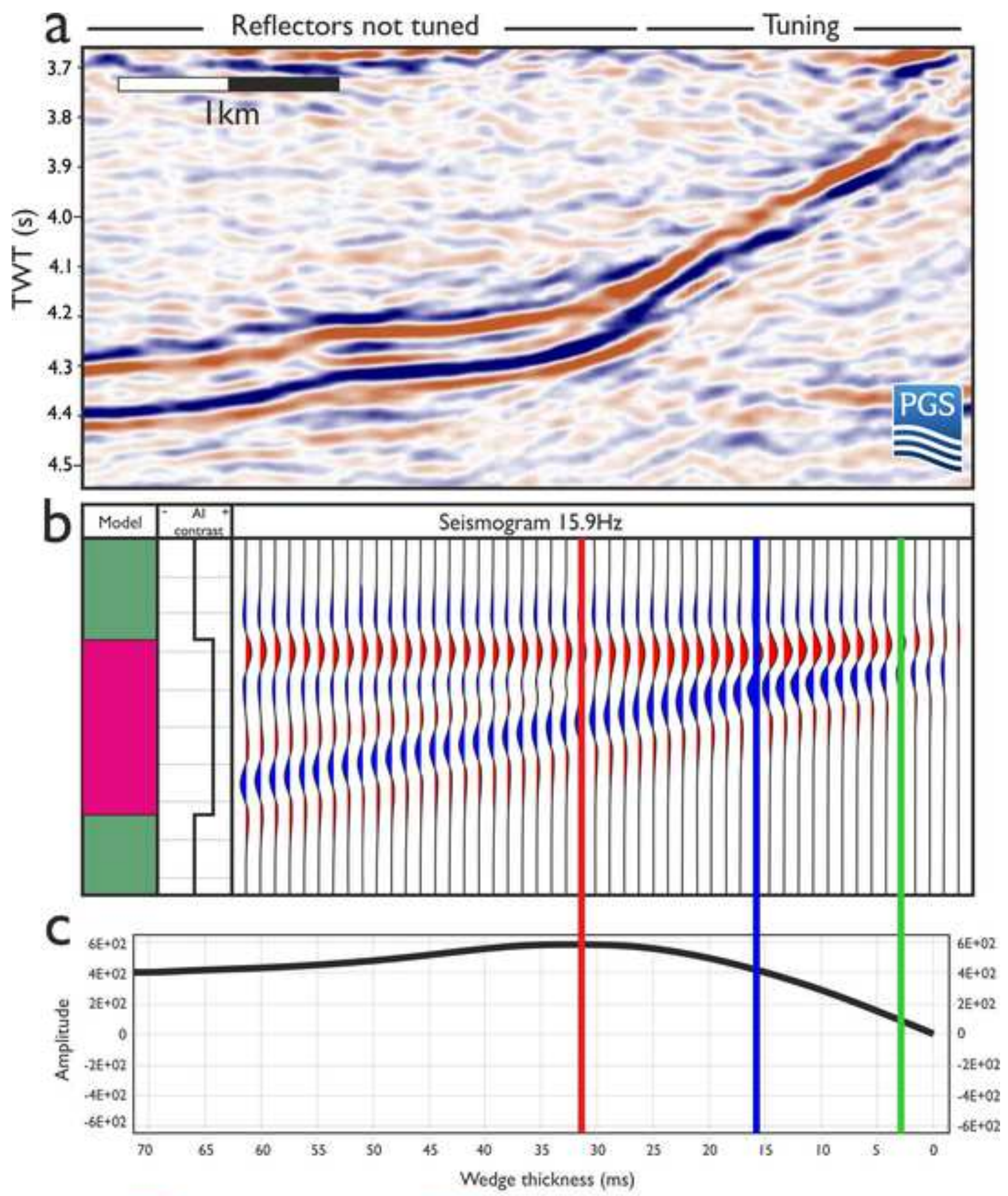

Dolerite: $5.5 \mathrm{~km} / \mathrm{s}, 2.9 \mathrm{~g} / \mathrm{cm}^{3} \square$ Background sediments (Chystone): $3048 \mathrm{~km} / 5,2.65 \mathrm{~g} / \mathrm{cm}^{3}$

$-N / 4-N / 8-N / 30-$ True thickness 

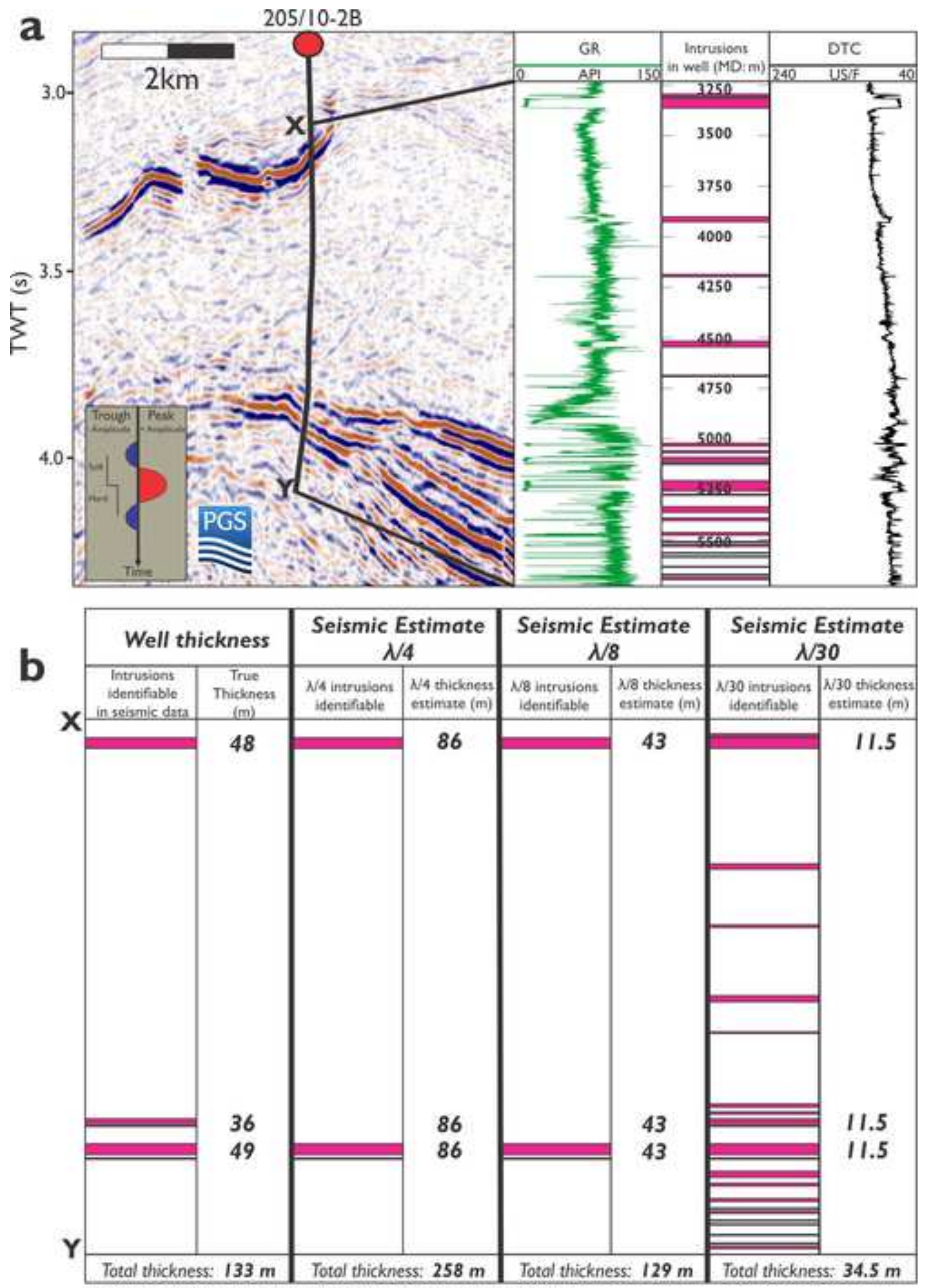

Frequency $15.9 \mathrm{~Hz}$, Dolerite interval velocity $5.5 \mathrm{~km} / \mathrm{s}$ 


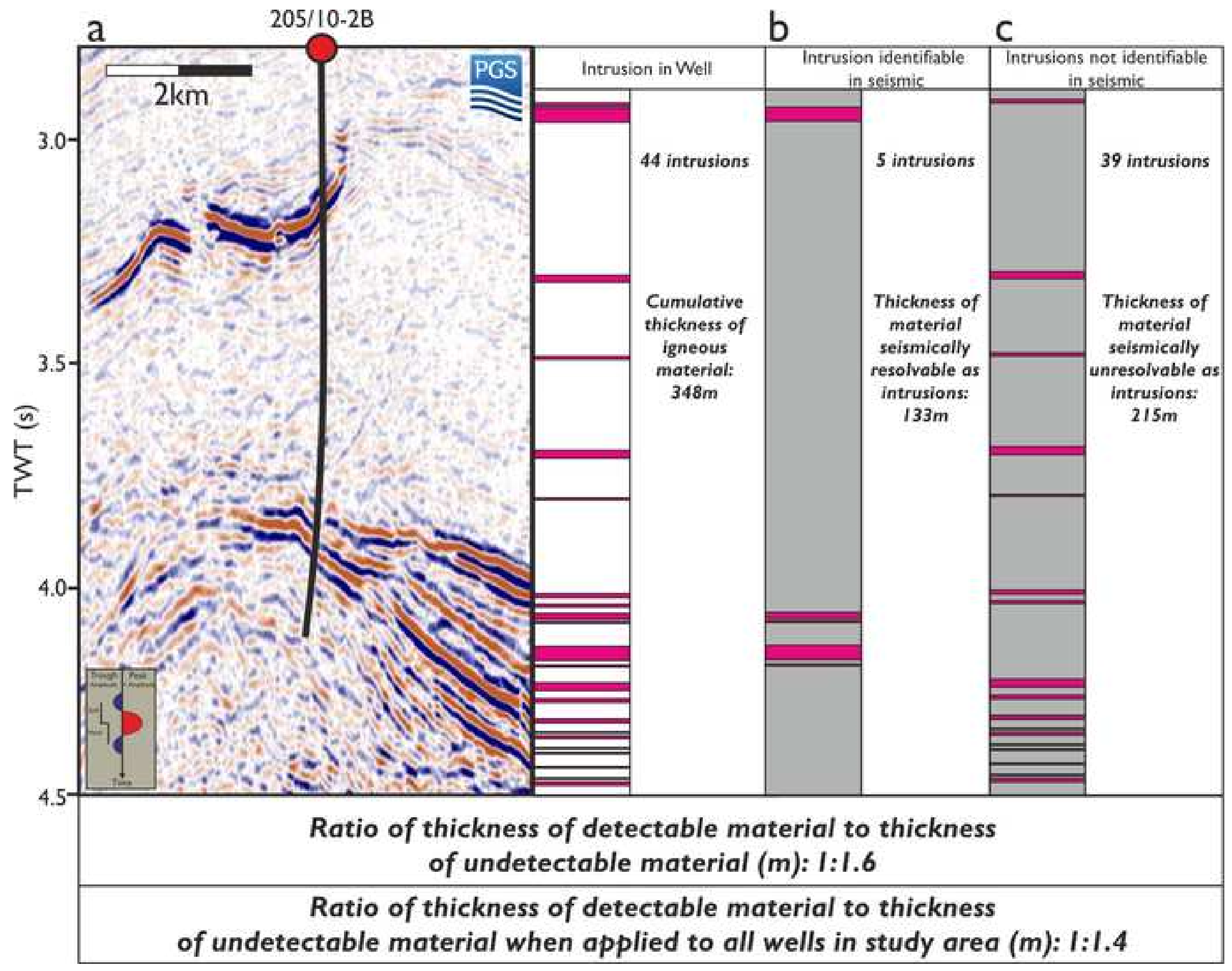




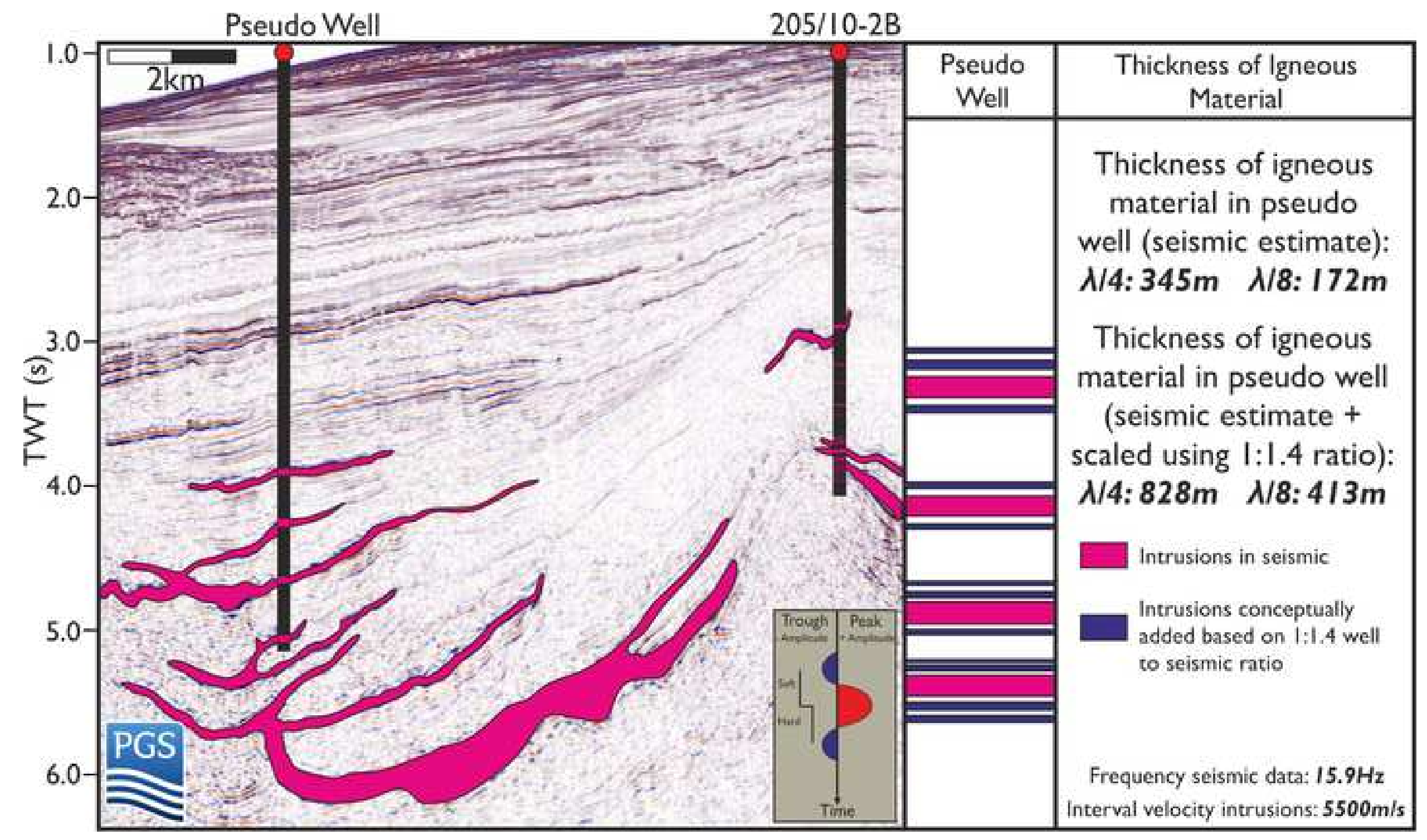


$N / 4$

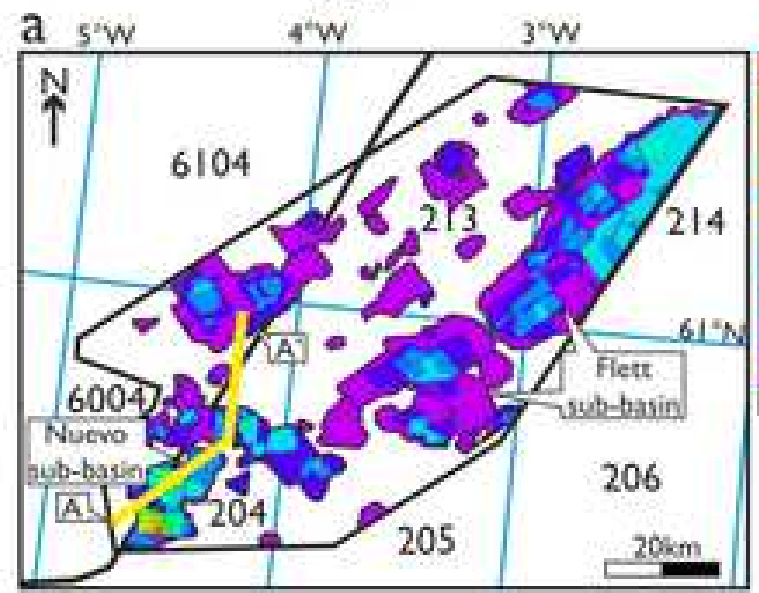

$\mathrm{N} / 4+$ Unseen Material (Maximum)
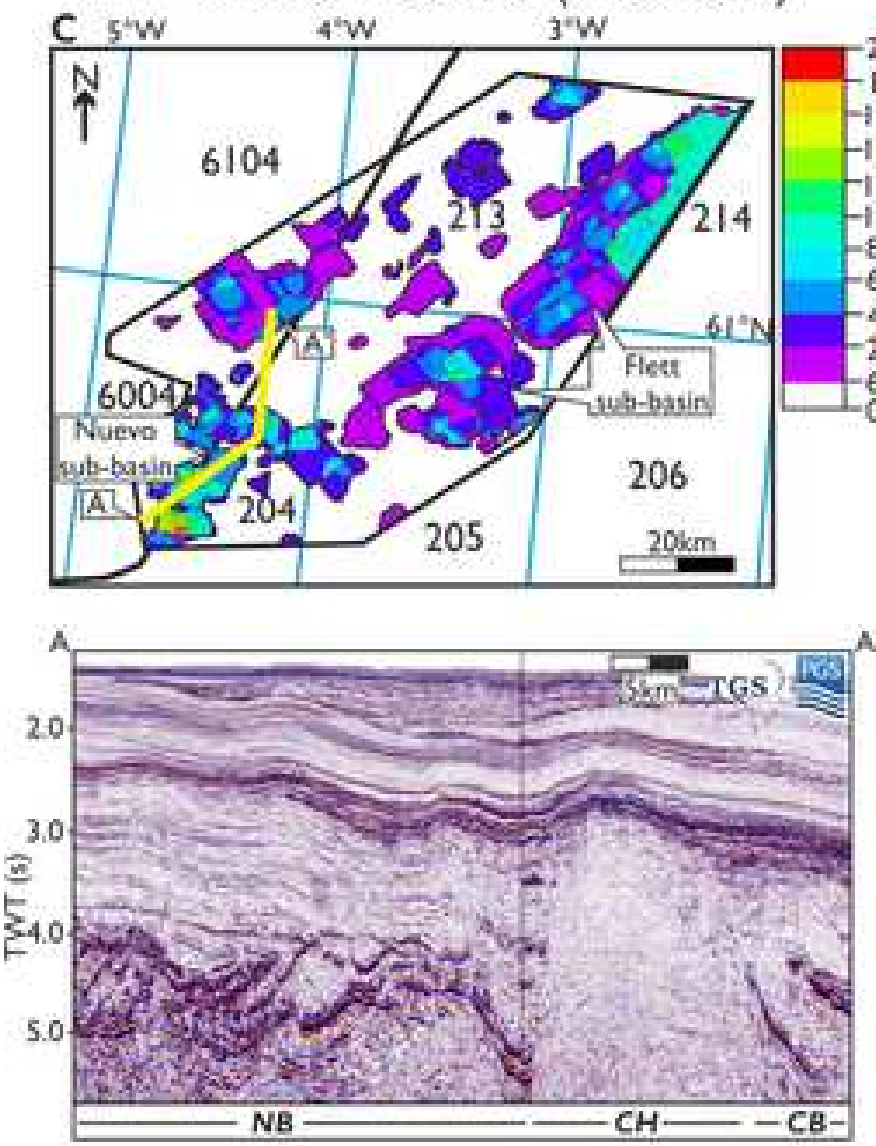

NB: Nuevo sub-basin CH:Cambo High CB:Corona sub-basin
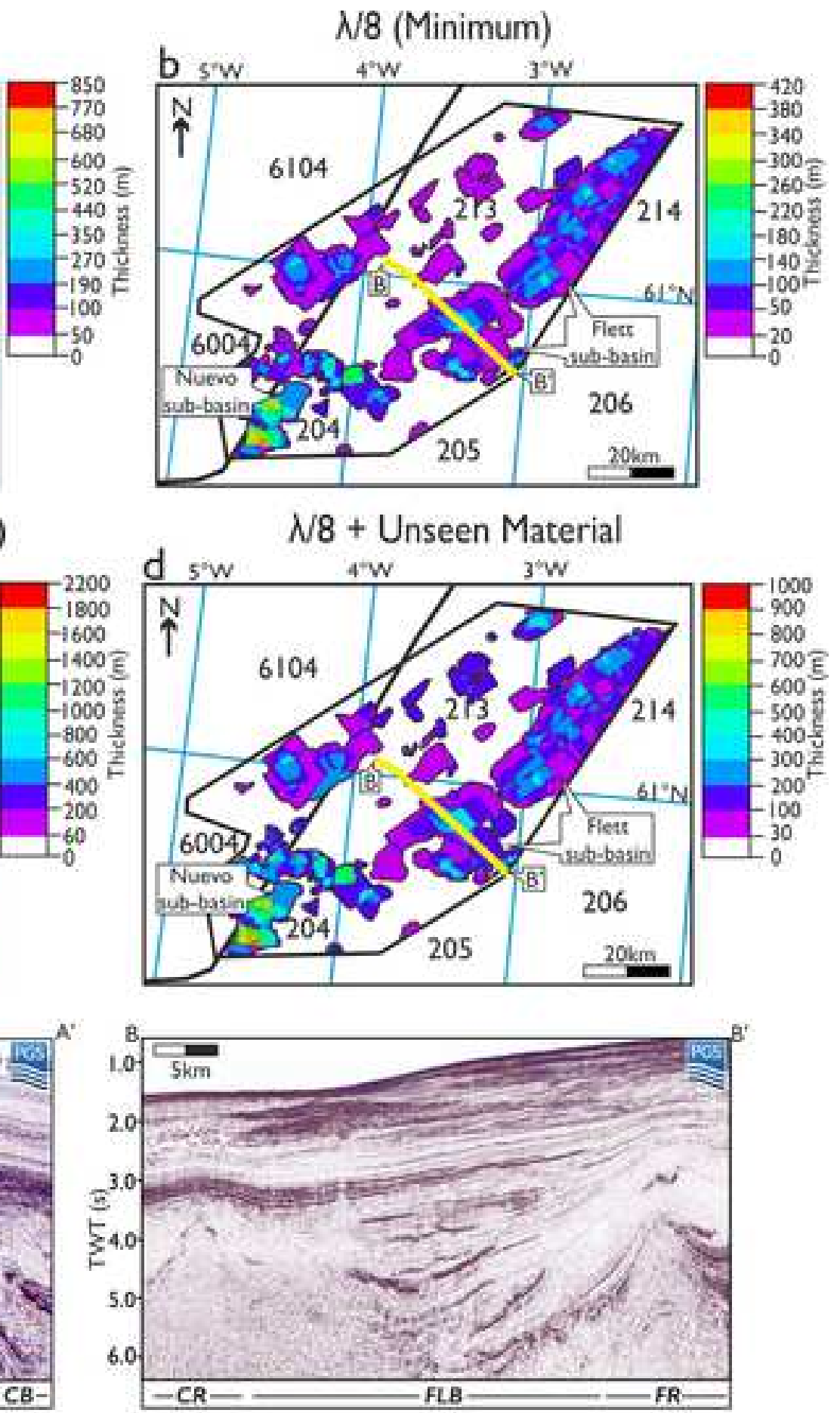

CR: Corona Ridge FLB: Flett sub-basin FR:Flett Ridge 


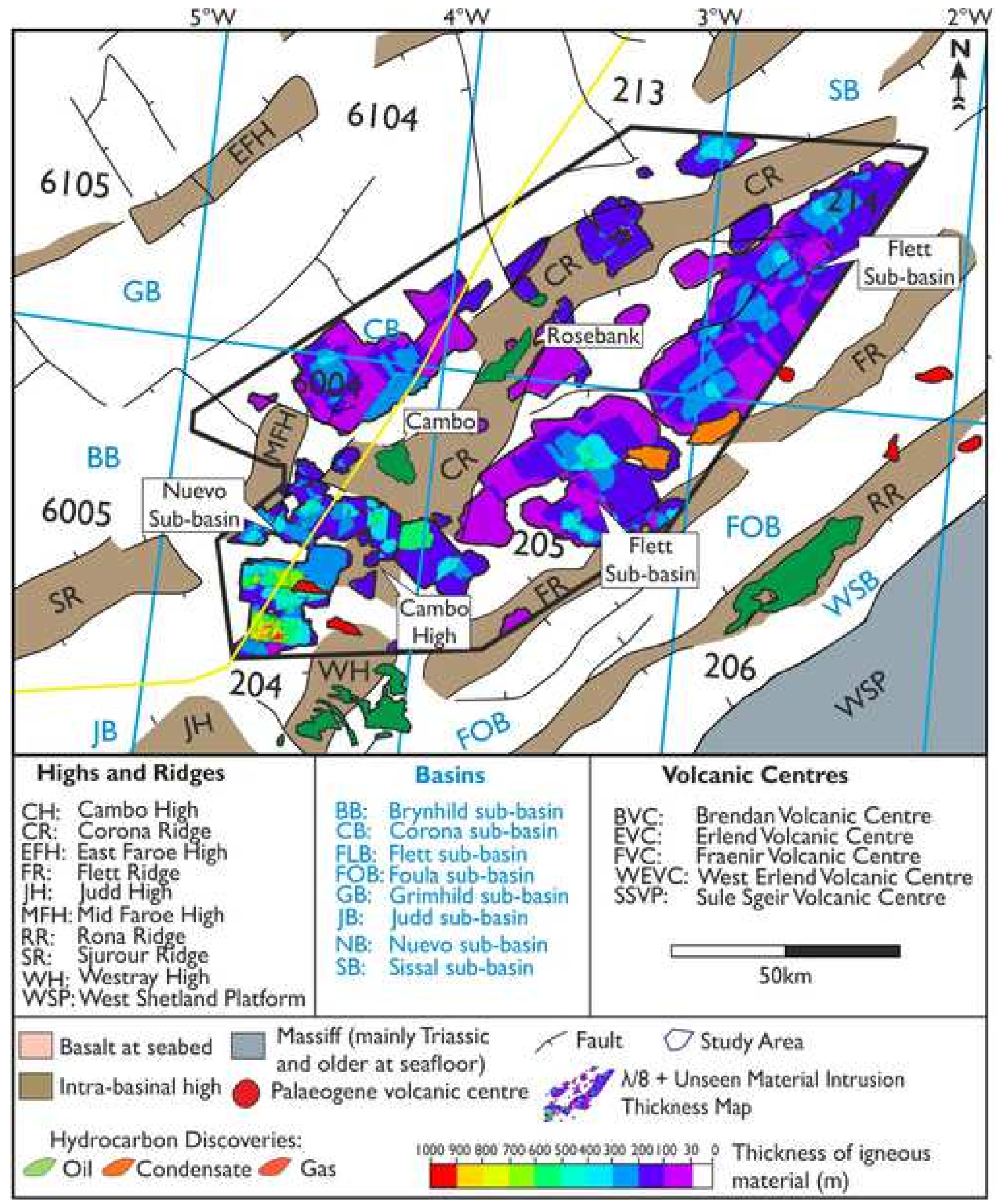




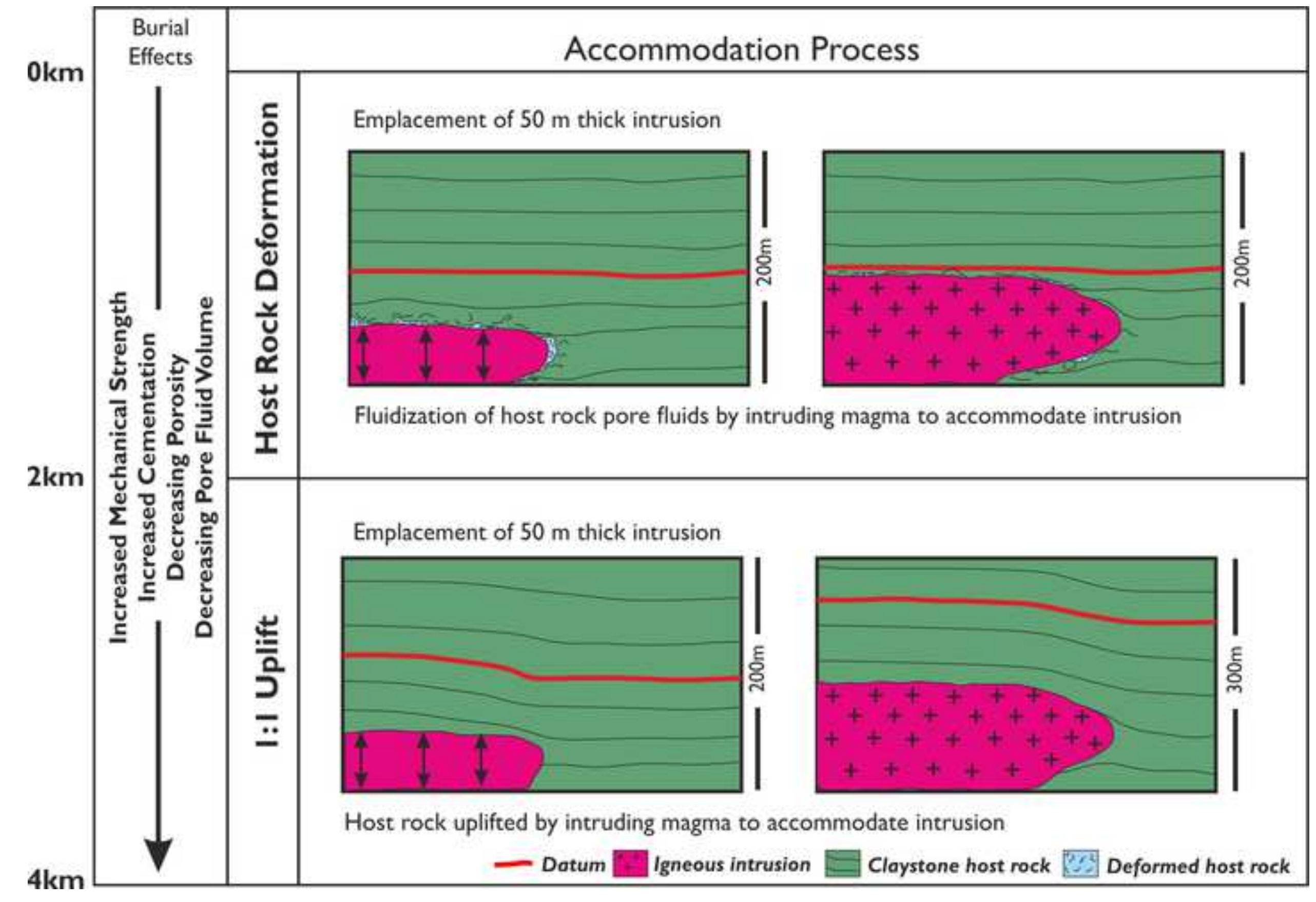




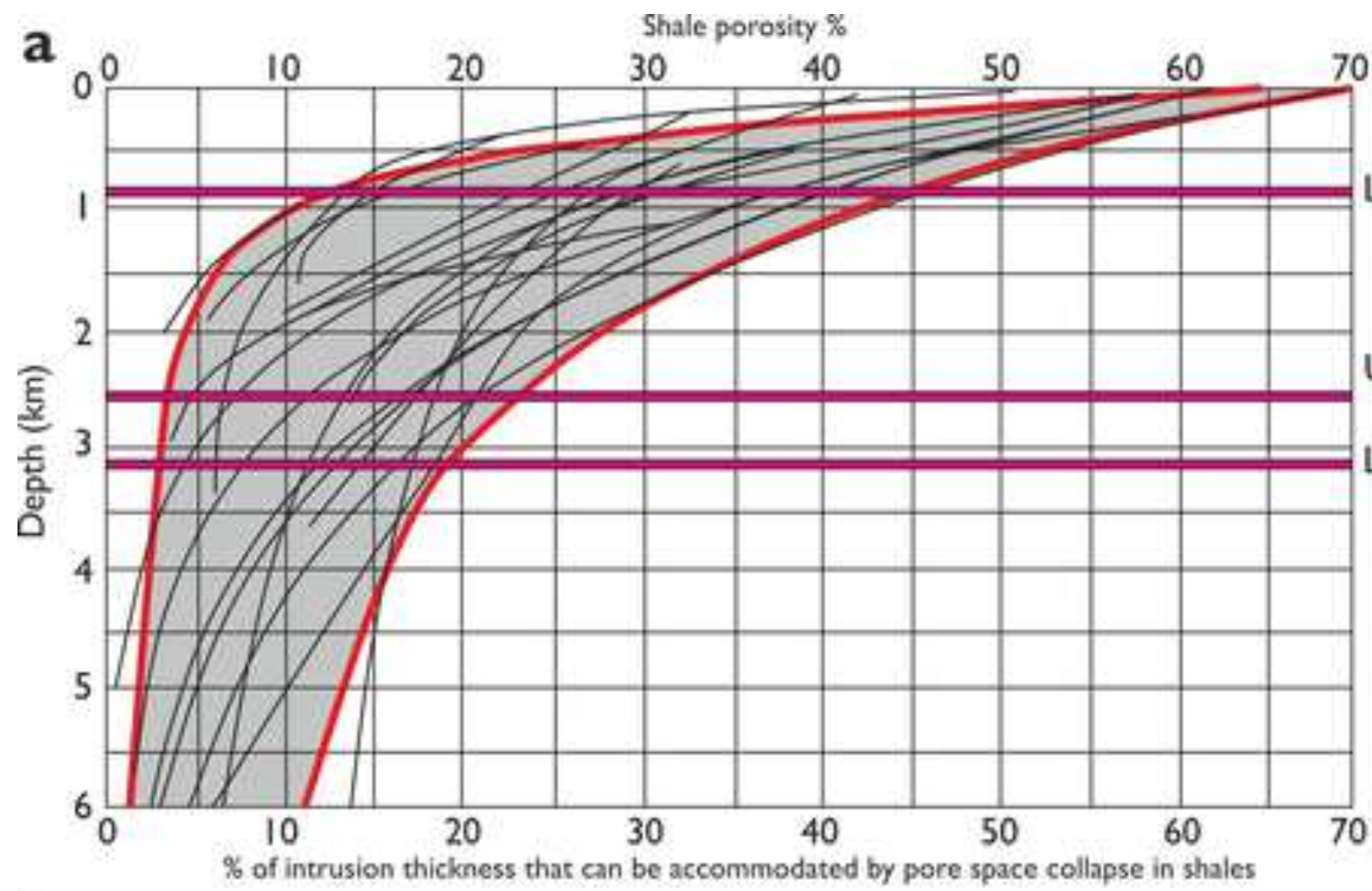

LP Paleo-depth of emplacement

UC Paleo-depth of emplacement LC Paleo-depth of emplacement

b

\section{LP: Lower Paleocene, UC: Upper Cretaceous, LC: Lower Cretaceous}

Average paleo-depth of emplacement for the Lower Paleocene: $850 \mathrm{~m}, 12-45 \%$ shale porosity

Average paleo-depth of emplacement for the Upper Cretaceous: $2500 \mathrm{~m}, 4-25 \%$ shale porosity

Average paleo-depth of emplacement for the Lower Cretaceous: $3276 \mathrm{~m}, 3-18 \%$ shale porosity

Intrusion of a $50 \mathrm{~m}$ thick sill at $800 \mathrm{~m}$ subsurface into a shale with $30 \%$ porosity

$35 \mathrm{~m}$ vertical upilf

$15 \mathrm{~m}$ accommodated by pore space collapse

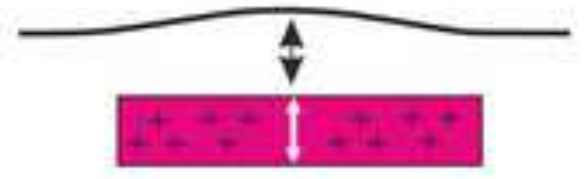

Intrusion of a $50 \mathrm{~m}$ thick sill at $2.5 \mathrm{~km}$ subsurface into a shale with $10 \%$ porosity

$45 \mathrm{~m}$ vertical uplift

$5 \mathrm{~m}$ accommodated by pore space collapse

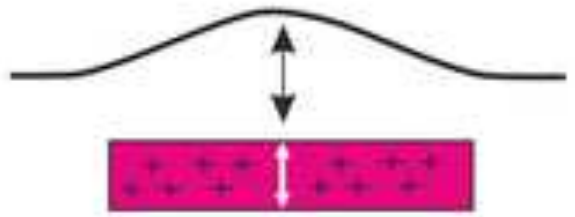


ID section Removal of intrusions post-emplacement and restoration of true sedimentary thickness

Conceptual 2D section of the Faroe Shetland Basin

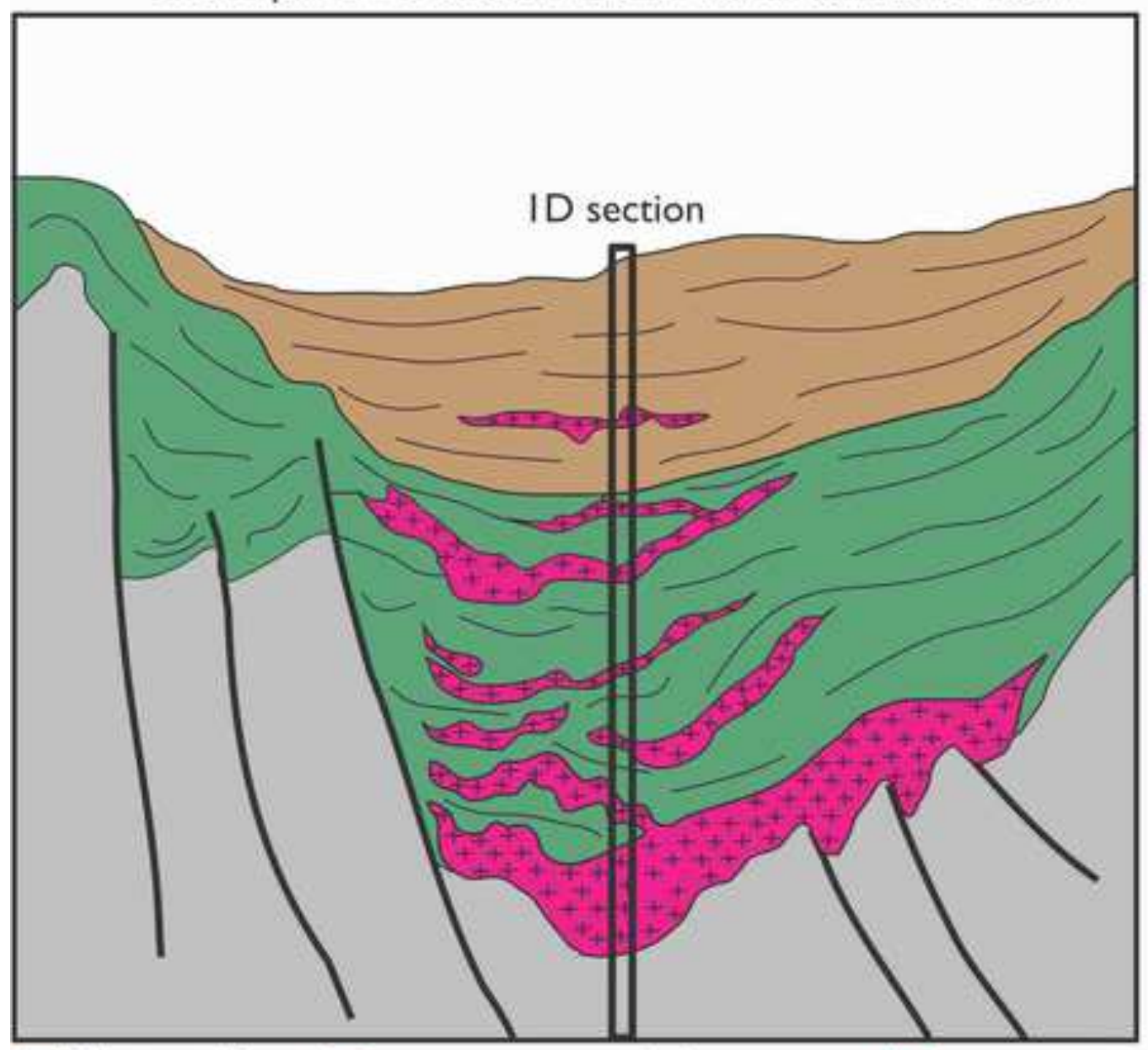

Paleogene to Recent

Cretaceous sediments $\square$ Pre-Cretaceous ${ }^{2}=$ Igneous intrusions

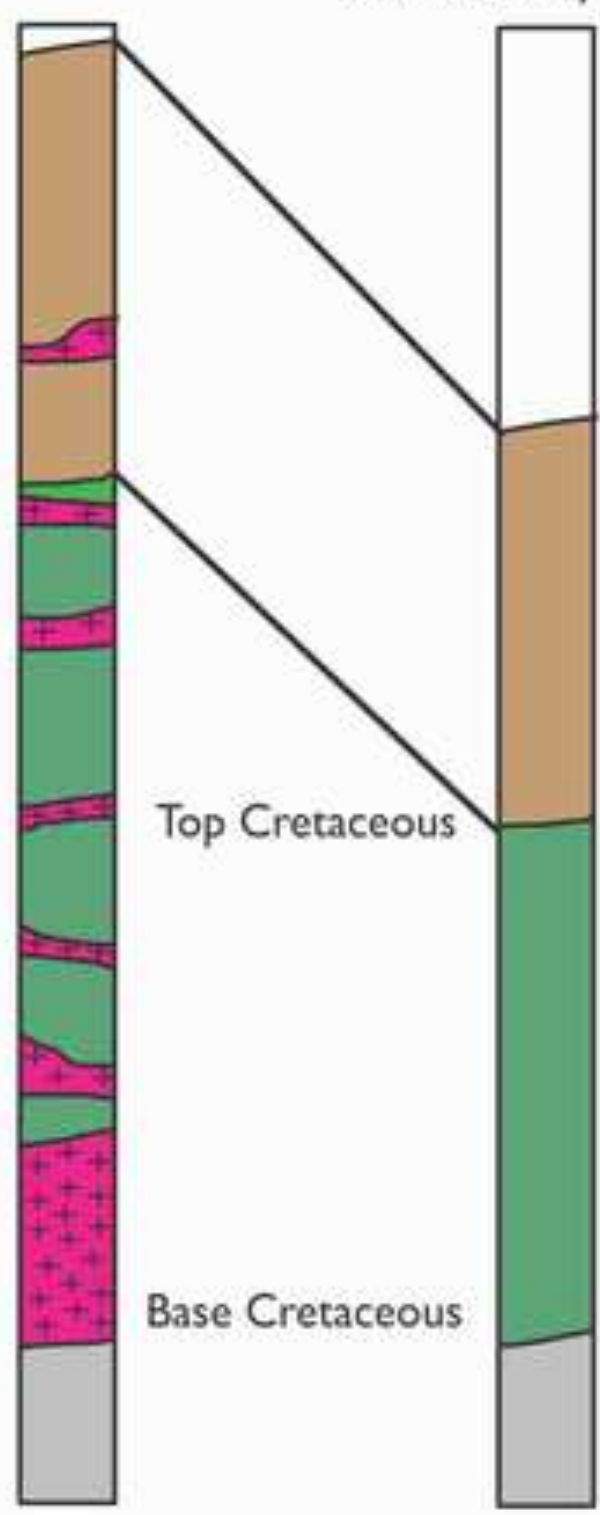

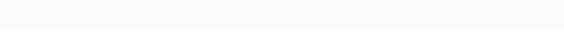

$$
\text { (1) }
$$




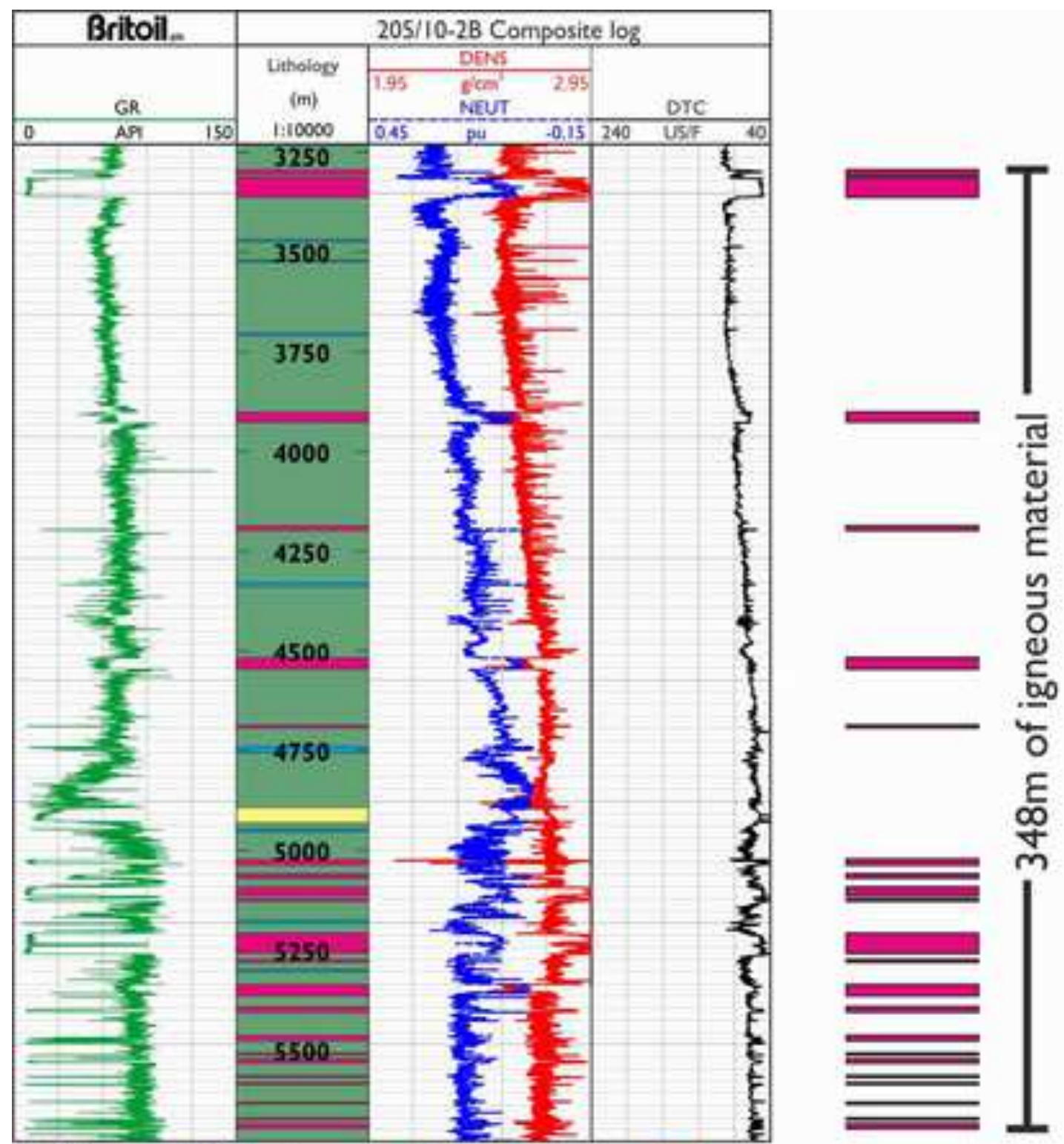

Claystones $\square$ Sandstone $\square$ Igneous intrusions $\square$ Limestone

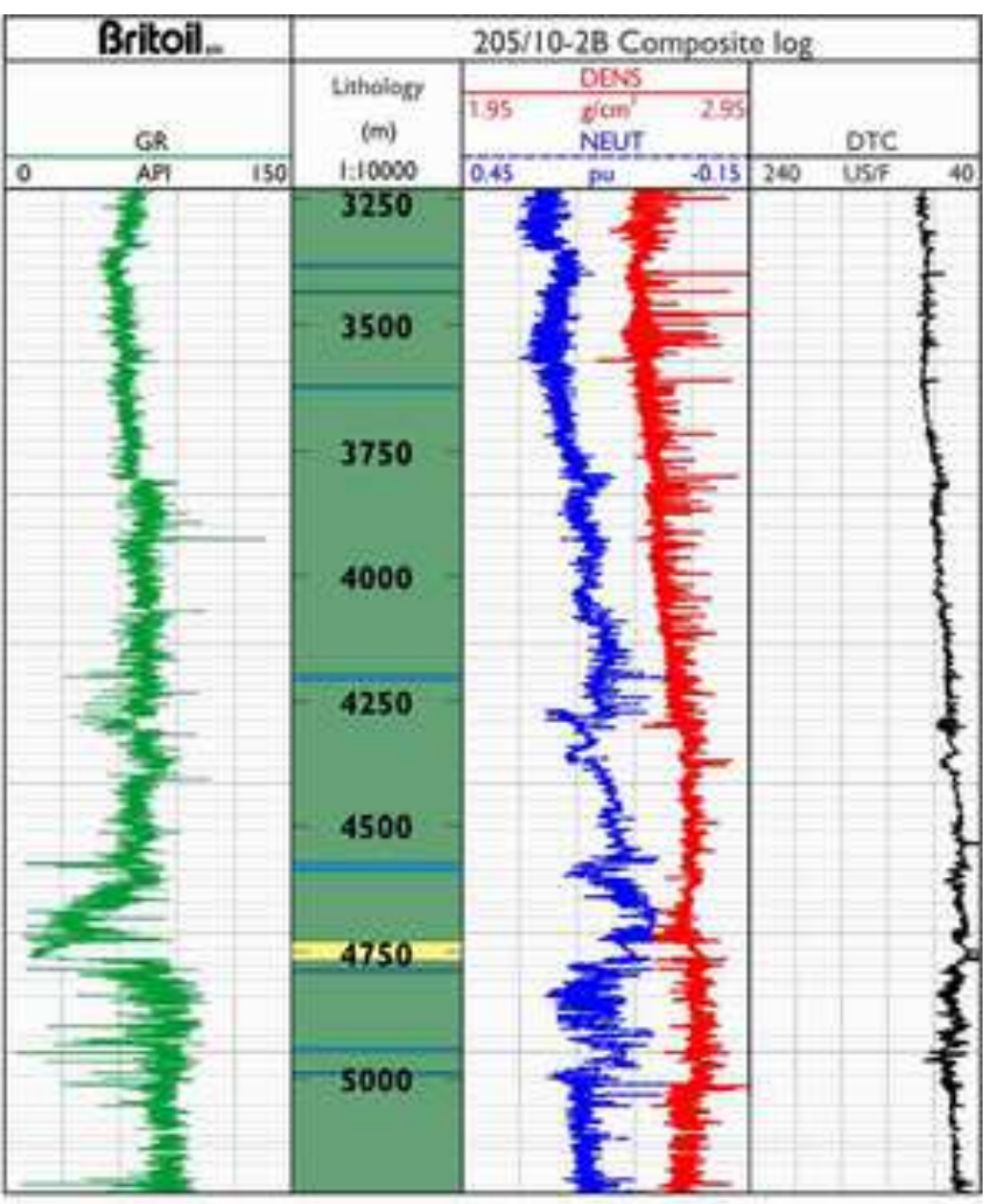

Cretaceous thickness with intrusions: $3240 \mathrm{~m}$

Cretaceous thickness without intrusions: $2892 \mathrm{~m}$

Assuming a geothermal gradient of $30^{\circ} \mathrm{C} / \mathrm{km}$ this results in a potential difference of $15^{\circ} \mathrm{C}$ 